\title{
Chapter 6 \\ Functional Biobased Composite Polymers for Food Packaging Applications
}

\author{
Hulya Cakmak and Ece Sogut
}

\begin{abstract}
Biobased polymers are of great interest due to the release of tension on non-renewable petroleum-based polymers for environmental concerns. However, biobased polymers usually have poor mechanical and barrier properties when used as the main component of coatings and films, but they can be improved by adding nanoscale reinforcing agents (nanoparticles - NPs or fillers), thus forming nanocomposites. The nano-sized components have a larger surface area that favors the filler-matrix interactions and the resulting material yield. For example, natural fibers from renewable plants could be used to improve the mechanical strength of the biobased composites. In addition to the mechanical properties, the optical, thermal and barrier properties are mainly effective on the selection of type or the ratio of biobased components. Biobased nanocomposites are one of the best alternatives to conventional polymer composites due to their low density, transparency, better surface properties and biodegradability, even with low filler contents. In addition, these biomaterials are also incorporated into composite films as nano-sized bio-fillers for the reinforcement or as carriers of some bioactive compounds. Therefore, nanostructures may provide antimicrobial properties, oxygen scavenging ability, enzyme immobilization or act as a temperature or oxygen sensor. The promising result of biobased functional polymer nanocomposites is shelf life extension of foods, and continuous improvements will face the future challenges. This chapter will focus on biobased materials used in nanocomposite polymers with their functional properties for food packaging applications.
\end{abstract}

Keywords Montmorillonite $\cdot$ Nanocellulose $\cdot$ Nanocomposite $\cdot$ Nanoparticles Nanoreinforcement

\footnotetext{
H. Cakmak (四)

Department of Food Engineering, Faculty of Engineering, Hitit University, Corum, Turkey e-mail: hulyacakmak@hitit.edu.tr

E. Sogut

Department of Food Engineering, Faculty of Engineering, Suleyman Demirel University, Isparta, Turkey
} 


\subsection{Introduction}

The main purpose of food packaging is to create a protective barrier against the transfer of moisture, water vapor and gases $\left(\mathrm{O}_{2}, \mathrm{CO}_{2}\right.$ and ethylene), protecting food against contamination from the storage environment, and in turn providing information about the ingredients, expiration date and other commercial information about the company which helps advertising for consumers, therefore, it has a communication function that allows traceability and safe disposed after use (Marsh and Bugusu 2007; Robertson 2013; Álvarez et al. 2017). In the early times, natural materials such as plant leaves, earthen pots, gourds and baskets were used for food preservation and storage (Risch 2009; Suárez and Gutiérrez 2017). Industrial revolutions and the increases in the rates of mass food production has helped improve packaging materials and technology, such as tin cans, glass bottles and jars, paper/board boxes, flexible plastic packaging, retort pouches are evolved, and today $100 \%$ biodegradable packaging materials from natural biomasses are replacing the current alternatives from non-renewable resources and unsustainable technologies (Brody et al. 2008; Gutiérrez 2018a).

According to the statistics published by European Bioplastics Organization (2018), 1200 kilotons of total bioplastics were assigned to biobased/nonbiodegradable sources, while biodegradable plastics correspond to 912 kilotons of the total bioplastics produced. The largest market share of biobased nonbiodegradable plastics belongs to polyethylene terephthalate (PET, 26.6\%), and the largest amount of biodegradable bioplastics belongs to starch mixtures (18.2\%) and polylactic acid (PLA, 10.3\%). However, the current values of bioplastics only correspond to $1 \%$ of total plastic production. Their projections, which include 2023, shows that the market shares of bioplastics increase linearly and will reach to 1288 kilotons for biodegradable bioplastics and 1328 kilotons for biobased nonbiodegradable ones.

Recently, global food companies are setting targets for the conversion available to $100 \%$ recyclable plastic packaging by 2025 as a contribution to the circular economy, and even some of their products currently on shelves are already become biodegradable sources and natural biomass. The food industry has also focused on the development of biobased packaging materials that have active properties to preserve and extend the shelf life of food products (Gutiérrez et al. 2017a; Álvarez et al. 2018). However, biobased films have inherent disadvantages, such as poor water vapor barriers and high moisture sensitivity which also affect their mechanical properties (Gutiérrez et al. 2016a, b; Herniou--Julien et al. 2019). It is thus required to improve the performance of biopolymers in terms of their mechanical, barrier and thermal properties, as well as processability to replace traditional polymer (Gutiérrez 2018b,c,d). In general, the use of small amounts of nano-fillers has proven effective in improving the barrier and mechanical properties of biopolymers to form films and coatings with satisfactory properties (Khan et al. 2014; ToroMárquez et al. 2018; Gutiérrez et al. 2019). The most recent approaches include biobased plastics with nanoparticles (NPs) and functional biobased active layers 
and the use of nanocomposites as carriers of active compounds such as antioxidants and antimicrobials (Yildirim et al. 2018; Merino et al. 2018a, 2019a).

Biobased composite/nanocomposite films for food packaging applications made from natural biomass (polysaccharides, proteins and lipids and waxes), and the effects of functional nanomaterials incorporated into the composites are discussed in this chapter.

\subsection{Biobased Polymers}

\subsubsection{Polysaccharide Biomass}

Biomass based on polysaccharides such as starch (native, thermoplastic etc.), cellulose and its derivatives (carboxymethyl cellulose, hydroxypropyl cellulose, hydroxypropyl methylcellulose, methyl cellulose), alginate, chitin, chitosan (Cs), maltodextrin, agar, pectin, carrageenan, heparin, chondroitin, glucomannan, pullulan, kefiran, curdlan and gums (gellan, guar, locust bean, mesquite, tara) can be used as pure polymer, polymer matrix or filler (Miller and Krochta 1997; Tharanathan 2003; Lacroix and Le Tien 2005; Falguera et al. 2011; Bonilla et al. 2012; Cirillo et al. 2015; Zia et al. 2015; Cazón et al. 2017; Gutiérrez 2017a; Araque et al. 2018). The mostly studied polysaccharide biomasses and their properties are summarized below.

Starch is composed of two macromolecules: amylose and amylopectin. Amylose is a linear polymer consists of D-glucose units linked with $\alpha-1-4$ bonds, while amylopectin consist of both linear glucose segments with $\alpha-1-4$ bond and $\alpha-1-6$ linked glucose segments at the branching points (Pérez et al. 2009; Bertolini 2010; Gutiérrez et al. 2014). The crystalline structure of native starch is attributed to amylopectin, while the crystalline and amorphous lamellas of amylopectin are packed in larger structures called block-lets (Bertolini 2010; Gutiérrez 2018e). However, the amorphous structure is dominant in the starch granules, since the amylose and most of the amylopectin are formed by an amorphous structure (Pérez et al. 2009). Temperature, pressure and $\mathrm{pH}$ may limit the film forming capacity of native starches regarding sensitivity to high shear, decomposition with temperature, retrogradation and syneresis (Bertolini 2010; Jiménez et al. 2012; Gutiérrez and Álvarez 2016; Gutiérrez and González 2016). Thus, the semi crystalline structure of starch is transformed into a homogeneous amorphous matrix to improve processing ability (Bertolini 2010). Applications of mechanical or thermal energy are required together with the presence of water for starch destructuring and, therefore, the production of thermoplastic starch (TPS) (Bertolini 2010; Thiré 2010; Puthussery et al. 2015; Gutiérrez et al. 2018a; Gutiérrez and Alvarez 2018). In addition to water, polyols such as glycerol and sorbitol provide the plasticizing effect, and increase flexibility and decrease the brittleness in films (Thiré 2010; Jiménez et al. 2012; Medina Jaramillo et al. 2016). Water, glycerol, sorbitol, propylene glycol, polyethylene 
glycol and other polyols, oligosaccharides, fatty acids and lipids are used as plasticizers for the formation of TPS (Bertolini 2010; Campos et al. 2011; Puthussery et al. 2015; Jawaid and Swain 2017). Plasticizers improve the oxygen permeability of extruded TPS. However, it may become susceptible to moisture, which accelerates the biodegradation of films (Siracusa et al. 2008). In addition, the incorporation of nano fillers such as phyllosilicates, cellulose/Cs based NPs, carbon nanotubes, metal oxides and other materials may improve the mechanical strength, water and gas barrier properties of starch based films (Xie et al. 2013; López et al. 2015; Gutiérrez and Alvarez 2017a). Native and thermoplastic starch is generally used in biodegradable packaging formulations due to its low cost, abundant sources and safe functions for the environment (Thiré 2010; Lagarón 2011).

Since the starch is cheap, renewable and has widely available sources, researchers are focused on functional properties of starches from different origins such as ahipa, cassava (called also tapioca), corn, elephant foot yam, palm, potato, sugar sago and wheat (Gutiérrez et al. 2015a,b,c,d). The mechanical properties of the matrix may change depending on the origin of starch (Medeiros et al. 2010; Jiménez et al. 2012).

Cellulose is composed of linear $\beta-1,4$ linked D-glucopyranose units, which is the main component of plant cell wall materials (Khan et al. 2014; Bracone et al. 2016). In addition to its extraction from plant sources such as woods, cotton, hemp, agricultural waste, aquatic plants and grasses, cellulose is also produced by Gluconacetobacter species in form of bacterial nanocellulose (Abdul Khalil et al. 2012; Khan et al. 2014; Azeredo et al. 2017). The purity, high mechanical strength, hydrophobicity and better gas barrier properties make bacterial cellulose more advantageous than plant-based alternatives (Khan et al. 2014; Cazón et al. 2017). However, the moisture sensitivity of bacterial nanocellulose impairs its oxygen barrier properties, especially at high relative moisture (Nair et al. 2014). After starch, cellulose is the second most abundant, cheap and renewable source for food packaging applications (Vilarinho et al. 2018). Nanostructures from cellulose such as cellulose nanofibrils, nanocrystals and nanowhiskers can participate as fillers of composite films due to their supreme mechanical and barrier properties due to their good dispersion into the polymer matrix (Khan et al. 2014). In addition to cellulose, hydroxypropyl methylcellulose and methylcellulose form transparent and flexible films with a good gas and lipid barrier structure (Cazón et al. 2017).

Cs is a linear polysaccharide consisting of 1,4-linked 2-amino-2-deoxy- $\beta$-Dglucan, and the amino group can form interactions with anionic groups in an acidic environment ( $\mathrm{Xu}$ et al. 2005). It is the deacylated derivative of chitin in alkaline medium (Kumar 2000; Elsabee and Abdou 2013). The biodegradable, non-toxic, biocompatible, antimicrobial and good film-forming nature of Cs makes it favorable for food packaging applications (Campos et al. 2011; Cazón et al. 2017; Merino et al. 2018b, 2019b). Cs has selective gas permeability and mechanical properties in addition to having a wide range of antimicrobial activity against bacteria, yeast and molds (Elsabee and Abdou, 2013; Cazón et al. 2017).

Cs is not thermally stable, therefore the processes that require heat applications such as extrusion, molding or heat sealing are not favorable for the production of 
Cs-based films (Cazón et al. 2017). In addition to improving the mechanical strength, water vapor permeability (WVP) can also be improved by mixing of Cs with other polysaccharides (alginate, cellulose, pectin, starch) or proteins (gelatin, whey proteins) (Xu et al. 2005; Elsabee and Abdou, 2013; Cazón et al. 2017).

Alginate is a linear copolymer of $\beta-(1-4)$ linked D-mannuronic acid and $\alpha-(1-4)$ linked L-guluronic acid extracted from brown algae (Abdollahi et al. 2013; Cazón et al. 2017). The alginate films have good mechanical strength but have a brittle nature with high WVP. However, the crosslinking of the alginate with polyvalent cations improve its WVP, increase its mechanical strength and improves the controlled release of incorporated functional materials (Campos et al. 2011; Cazón et al. 2017).

Pullulan is a water-soluble exopolysaccharide which is synthesized by Aureobasidium pullulans (Cirillo et al. 2015; Chen et al. 2017). Pullulan-based films are biodegradable and non-toxic, as well as have good oxygen permeability, transparency, oil and grease resistance (Tharanathan 2003; Chen et al. 2017). Pullulan can be extruded as a film with good mechanical stability (Tharanathan 2003; Chen et al. 2017).

Kefiran, like pullulan, is also a water-soluble exopolysaccharide produced by the microorganisms present in kefir grain flora (Motedayen et al. 2013). It has a good film-forming capacity depending on the plasticizer used (Ghasemlou et al. 2011). Due to their hydrophilic nature, the polysaccharide films are permeable to water vapor (Lacroix and Le Tien 2005). Although the WVP values of kefiran films are similar or even better than the corn starch and Cs-based films (Piermaria et al. 2009).

\subsubsection{Protein Biomass}

The protein biomasses used in biobased composite film formulations include whey proteins, casein, gluten, soy protein, lentil, peanut, mung bean, quinoa, canola proteins, kafirin, zein, egg albumen, collagen, fibrin, fibroin, spidroin, gelatin (fish skin, other animal origin), myofibrillar protein, keratin (hair), sericin (silk) (Baldwin et al. 1995; Miller and Krochta 1997; Anyango et al. 2011; Plackett 2011; Abugoch et al. 2016; Doblhofer et al. 2016; Cazón et al. 2017; Li et al. 2017; Garrido et al. 2018; Tomadoni et al. 2020).

Whey proteins have good gas barrier properties, good film-forming capacity, biodegradability, elasticity, transparency and can act as a potential carrier of antioxidant and antimicrobial agents, therefore, they are the best alternative among other protein sources (Miller and Krochta 1997; Sothornvit et al. 2009; Ramos et al. 2012; Oymaci and Altinkaya, 2016). In addition, whey proteins have a nature compatible with metal oxide NPs, nanocellulose, zein NPs, nanoclays and are suitable for crosslinking or lamination with lipid matrix (Miller and Krochta 1997; Bourtoom 2009; Sothornvit et al. 2009; Zolfi et al. 2014; Oymaci and Altinkaya 2016; Qazanfarzadeh and Kadivar 2016). 
The WVP and mechanical strength of protein-based films are comparably lower than the synthetic polymers such as low-density polyethylene (LDPE), ethylene vinyl alcohol $(\mathrm{EVOH})$ and cellophane. This is due to the hydrophilic structure of proteins (Bourtoom 2009; Hernandez-Izquierdo and Krochta 2008). However, gas $\left(\mathrm{O}_{2}, \mathrm{CO}_{2}\right.$, and aroma) and water permeability of films are improved when the $\mathrm{pH}$ of the solution is higher than the isoelectric point of the proteins (Olivas and BarbosaCánovas 2005). In addition, the inclusion of NPs such as nanocellulose, montmorillonite (Mt) and silver (Ag) NPs improves the water and oxygen barrier properties, mechanical strength and thermal stability, in addition to providing antimicrobial properties for the protein-based nanocomposite films (Bae et al. 2009; Kumar et al. 2010; Pereda et al. 2011; Kanmani and Rhim 2014; Qazanfarzadeh and Kadivar 2016).

Zein films have a strong and glossy structure, resistant to grease, and crosslinking or the addition of glycerin improves the mechanical properties of these films (Tharanathan 2003). Although the brittleness is reduced with the addition of plasticizer, the barrier properties (water vapor and gas) of zein-based films are negatively affected (Arora and Padua 2010). Similar to zein, the addition of plasticizer reduces the brittleness of whey protein films (Plackett 2011). But the type and ratio of plasticizer together with the storage environment are effective on oxygen permeability values of whey protein-based films (Miller and Krochta 1997; Ramos et al. 2012).

\subsubsection{Lipid and Wax Biomass}

The first development of food coating was the manufacture of wax-based coating on fruits to minimize dehydration and provide a bright appearance (Ansorena et al. 2018). Fat and oil-based biomasses such as bees, candelilla, carnauba and rice bran waxes, lecithin, shellac, mineral and vegetable oils, stearic acid, lauric acid, glycerin, triolein, fatty acid sucrose esters and resins are examples of lipids and waxes that are used in food packaging applications (Baldwin et al. 1995; Morillon et al. 2002; Rhim and Shellhammer 2005; Bonilla et al., 2012; Robertson, 2013). Synthetic waxes such as paraffin and petroleum waxes are also used for food packaging (Robertson 2013). In addition to using the lipids as a matrix in biocomposites, essential oils from plants are used as antimicrobial agent in composite films (Debeaufort et al. 2000; Morillon et al. 2002; Bourtoom 2009).

Lipids and waxes are used in the composite films for their barrier properties against water vapor (Rhim and Shellhammer 2005). The long fatty acid chains are effective in reducing WVP values. However, fatty acid chains with more than 18 carbon atoms cause a negative effect on WVP values, due to heterogeneity in the polymer structure (immiscible mixtures) (Morillon et al. 2002). Self-standing lipid films have low processability due to their low mechanical strength (Rhim and Shellhammer 2005). Although its strength may be improved with the addition of hydrocolloids, either with lamination or making emulsions (Falguera et al. 2011). Lipid-based films and waxes have low moisture permeability due to their 

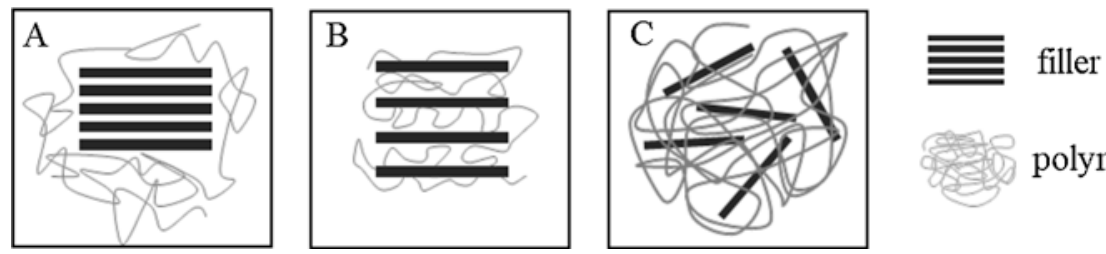

polymer

Fig. 6.1 Schematic representation of tactoid (A), intercalated (B) and exfoliated (C) structures

hydrophobic nature (Morillon et al. 2002). Polymorphism and crystalline structure influences the WVP of films formed by lipids and waxes (Morillon et al. 2002). The water vapor transmission rate (WVTR) had also been comparably lower when solid fat is used as a layer in the case of lipids in bilayer films (Debeaufort et al. 2000).

\subsection{Nanoreinforcement}

There are three types of biobased nanocomposite configurations: phase-separated (tactoid), intercalated, and exfoliated (Rhim et al. 2013). These three main configurations are presented in Fig. 6.1.

Tactoid structure is formed when a polymer and a filler are immiscible due to their poor chemical interactions, and as a consequence the filler layers are not separated (Tang et al. 2012). The tactoid structure that predominates in conventional composite materials, which results in the stacking of the filler in the matrix, thus causing poor properties for the material (Alexandre et al. 2009). The intercalated structures are obtained by direct extension of the filler to create spaces between the layers when the polymer chains enter the primary space of the filler. The intercalation arises from the permeation of the polymer chains within the filler layers. This results in a well-organized multilayer structure containing polymer/filler layers with recurrent distances (Weiss et al. 2006). The exfoliated nanocomposites are formed when the polymer chains penetrate into the arranged and randomly dispersed filler layers in the polymer matrix (Ludueña et al. 2007). These structures are obtained after filler loses its layered structure and is isolated into single sheets within the constant polymer phase due to the strong chemical interactions between the polymer and the filler (Turan et al. 2018). Exfoliation is the best way to obtain an ideal interaction between the filler and polymer matrix (Adame and Beall 2009; Azeredo 2009).

The use of inorganic nano-fillers for the manufacture of nanocomposites has gained interest thanks to its distinctive properties which are suitable for numerous industrial applications. Although many nano-fillers have potential to improve the performance of polymers, the packaging industry has concentrated on using layered inorganic fillers such as clays and silicates, due to their availability, low cost and comparatively simple processability. Its presence in polymer formulations increases the tortuosity, thus a penetrating molecule is forced to diffuse through a longer 
pathway within the film, and the resulting film has excellent barrier properties (Adame and Beall 2009). The mechanical strength of biopolymer films is also improved, thus increasing the glass transition temperature $\left(\mathrm{T}_{\mathrm{g}}\right)$ and thermal degradation temperature, while some studies have reported a decrease in transparency as minor disadvantages of fillers on polymer (Yu et al. 2003; Petersson and Oksman 2006; Weiss et al. 2006; Cyras et al. 2008). In this section, the use of inorganic fillers (e.g. clay minerals) and natural fillers (e.g. cellulose based nanostructures) in the nanocomposite films will be discussed.

\subsubsection{Clays and Silicate-Based Fillers}

Clay minerals contain tetrahedral and octahedral sheets which are negatively charged or neutral layers of hydrated aluminum phyllosilicates (Murray 2000; Unalan et al. 2014; Gutiérrez et al. 2017b). The superimposition of tetrahedral and octahedral sheets creates layered structures, which then form a layer called platelet. The isomorphic replacement of aluminum and/or silicon with a lower-valence atom causes a negative surface charge for minerals. In some clay groups, the negative surface charge is balanced with positive inorganic ions found in the interlayer (Unalan et al. 2014). The cations have an important effect on the swelling behavior of clay when in contact with water molecules. In general, two arrangements of main sheets are observed, namely $1: 1$ and $2: 1$, in nanoclays (Unalan et al. 2014). The nanoclays are grouped as smectite, kaolinite, halloysite, etc., according to their morphology and chemical structure (Fig. 6.2).

$\mathrm{Mt}$ is the most commonly used filler in the formation of nanocomposites. The surface of $\mathrm{Mt}$ is negatively charged because the trivalent Al-cation is partially replaced with the $\mathrm{Mg}$ divalent cation. Sodium and calcium ions, which are hydrated between the layers, balance the charge (Manias et al. 2001). The weak forces that hold layers together allow water and other polar molecules to penetrate between the layers that expand the matrix (Chin et al. 2001). In addition to improving the tensile strength and gas barrier properties of composite films, modified Mt particles also show an antibacterial effect that increases the potential use for food packaging applications (Sothornvit et al. 2009; Souza et al. 2012; Kanmani and Rhim 2014). However, the migration of the metal from packaging film to the food due to the addition of clay should be observed.

Kaolinite is a the crucial mineral among the group of kaolin clays, and is a layered silicate consisting of a tetrahedral sheet with dioctahedral sheet layers (Murray 2000). The structure of kaolinite provides great cohesive energy regarding hydrogen bonds between adjacent layers (Sanchez-Garcia et al. 2008a). In addition to its lower aspect ratio, kaolinite has a low absorption capacity, associated with the low surface area and the minimal layer loading (Krishnamachari et al. 2009). Although it is inexpensive, abundant and environmentally friendly, kaolinite is rarely used for the preparation of nanocomposites due to the difficulties faced by intercalation of polymers. Within the kaolin group, halloysites represent a dominant form of hollow 
A
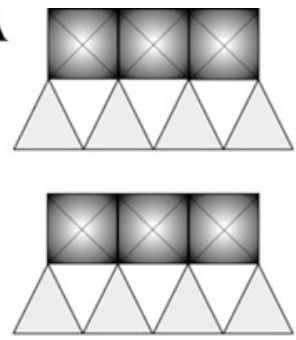

kaolinite
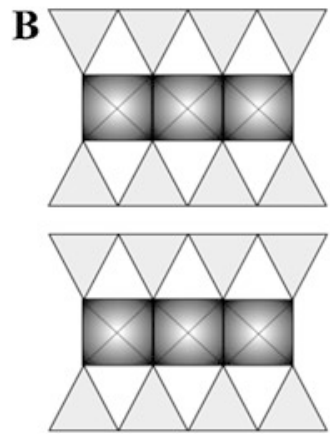

pyrophyllite

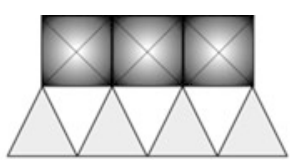

water

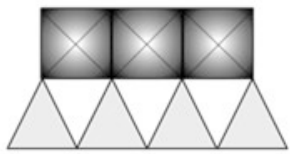

halloysite

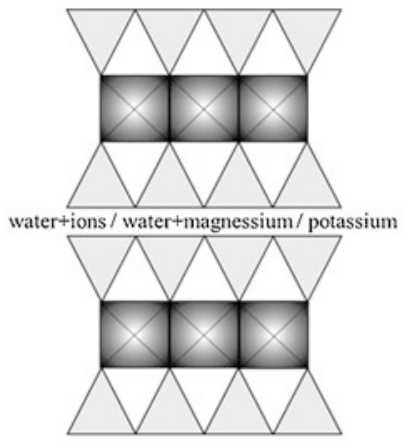

smectite/ vermiculite / illite
Octahedral

Tetrahedral

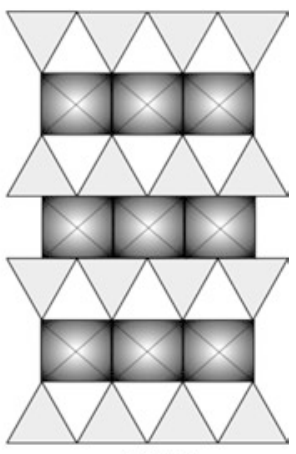

chlorite

Fig. 6.2 Schematic representation of clay groups according to the type of layer: 1:1 (A) and 2:1 (B)

tubes formed by two-layered aluminosilicate clay (Yah et al. 2012). Halloysite has attracted the attention of researchers because they can readily be dispersed into polymers without exfoliation due to the tubular shape and less surface hydroxyl groups (Du et al. 2010). Halloysites can be used in the composites to release active agents such as antimicrobials, oxygen scavengers, etc.

Double layered hydroxides are also known as non-silicate oxides and hydroxides with similar properties to those of clay minerals (Forano et al. 2006). Hydrotalcite is one of the most characteristic minerals in this group. The hydroxide layers have a positive surface charge contrary to layered silicates. In these layers, the $\mathrm{Mg}$ atoms are replaced by $\mathrm{Al}$ atoms that are counteracted by anions located between consecutive layers (Sorrentino et al. 2005). Many of biobased components are negatively charged, therefore, hydrotalcites are ideal fillers for biobased polymers (Rives 2001).

Mica is a group of phyllosilicate minerals, which can be classified into two groups: flexible micas and brittle micas. In flexible micas, the negatively charged tetrahedral sheet is balanced by a monovalent cation located between layers (generally potassium) while in brittle micas, a higher negative charge of the tetrahedral sheet is replaced by a divalent cation such as calcium (Unalan et al. 2014). The cations presented between the mica layers are anhydrous and do not have an internal surface area similar to pyrophyllite. 
The talc has a plate-like structure with magnesium-oxygen/hydroxyl octahedral layers packed in two layers of tetrahedral silica (López et al. 2015). Highly lamellar talc is associated with large single platelets, while microcrystalline talc has small platelets. Talc has naturally poor interactions with nonpolar materials and has a high surface energy (Gorrasi et al. 2018). Talc is mostly used to improve thermal resistance, mechanical properties and dimensional stability of the films (Sakthivel and Pitchumani 2011).

Zeolites are aluminosilicates in the form of hydrated crystals with a highly porous structure due to the system of three-dimensional channels. Zeolites have univalent and divalent cations. Water molecules are the other components located in the system of channels that give the exchange capacity and dehydration/rehydration capacity to zeolites (Gascon et al. 2012). The underlying reason for the addition of zeolites into the polymer is to form mixed-matrix membranes and improve the mechanical and thermal properties.

\subsubsection{Metallic Nanostructures}

Ag NPs are one of the most used metals for the production of active biobased nanocomposites, due to their antimicrobial properties against a wide variety of microorganisms (Dallas et al. 2011). The widely recognized mechanisms of antimicrobial activity are: (1) the interaction of $\mathrm{Ag}^{+}$ions with negatively charged nucleic acids contributes to the disruption of metabolic processes, the disintegration of cell wall causing the cell death (Kanmani and Rhim 2014), and (2) the membrane binding to the surface causes morphological changes and then the structural integrity is lost (Sondi and Salopek-Sondi 2004; Álvarez et al. 2018). Ag NPs are increasingly used in the formation of nanocomposites for food packaging applications, since it provides slower release rates with lower acute antimicrobial responses due to the high aspect ratio and, thus improving its surface reactivity (Egger et al. 2009).

Copper is another well-recognized nano-sized particle that exhibits a lower biocidal activity compared to Ag ions. However, the use of copper in nanocomposites is restricted because it is considered as toxic when in contact with food and increases the oxidation rate of the food product (Fernández et al. 2010).

Metal oxides (e.g. $\mathrm{MgO}, \mathrm{TiO}_{2}$, and $\mathrm{ZnO}$ ) also show antimicrobial activity against various microorganisms, such as bacteria, yeasts and molds. Nanocomposites containing titanium dioxide $\left(\mathrm{TiO}_{2}\right)$ NPs show antimicrobial properties thanks to their photocatalytic activity, related to their crystal structure. The antimicrobial effect of $\mathrm{TiO}_{2}$ NPs is associated with the generation of $\mathrm{O}_{2}$ and hydroxyl radicals after irradiation at higher energies than the band gap. The organic molecules are then oxidized by reactive oxygen species that lead to cell death (Llorens et al. 2012). In addition to their antimicrobial activity, $\mathrm{TiO}_{2} \mathrm{NPs}$ protect food products against the oxidizing effect of ultraviolet (UV) irradiation, as well as maintain optical clarity related to their efficient short-wavelength light absorbing properties (Duncan 2011). Zinc 
oxide $(\mathrm{ZnO})$ particles have an antimicrobial activity similar to that of other metal oxides, and are preferred for its low cost and its UV-blocking properties.

\subsubsection{Carbon-Based Nanomaterials}

Graphene is the building unit of graphite. The exfoliated graphite nanoplatelet or graphite nanoplatelet is a three-dimensional layered mineral allotrope and contains a stack of more than 10 layers of carbon atoms (Gorrasi et al. 2018). A thinner version of graphene is known as graphene nanosheets and has different derivatives that are presented as oxide, reduced oxide and nanoplatelets. Among them, graphene oxide is rich in functional groups such as carboxyl, epoxide and hydroxyl, thus has a high potential to be used in biobased nanocomposite materials. Nanoplatelets and nanosheets of graphite have lower functional groups, and they are hydrophobic, therefore do not contribute to polar interactions or hydrogen bonding.

In general, the exfoliation of graphite in layered graphene sheets is based on the disruption of van der Waals-like forces between the graphite layers. The use of graphene within a composite improves the mechanical and barrier performance, as well as electrical and thermal conductivity (Unalan et al. 2014).

Carbon nanotubes are formed by concentric tubes entitled as single-wall or multi-wall nanotubes. These fillers show remarkably high aspect ratios and Young's modulus $(E)$ with a high reinforcing capacity of biobased polymers (Zhou et al. 2004). These fillers are used not only for their performance to improve thermal/ mechanical/barrier properties of polymer composites, but also for their compatibility with chemicals, metal/metal oxide/chalcogenides NPs, and non-scattering electron transports (McEuen et al. 1999; Baur and Silverman 2007).

\subsubsection{Polysaccharide Based Nanostructures}

Cellulose-based nano-fillers are classified into three groups: cellulose microfibers, nanocrystalline cellulose or cellulose nanowhiskers (Azizi Samir et al. 2005). Cellulose nanofibers include a group of elongated molecules, which are stabilized by hydrogen bonds. Cellulose nanowhiskers consist of the crystalline part of the micro fibrils, which is obtained by acid hydrolysis (Gorrasi et al., 2018). The microfibrils are composed of crystalline and amorphous parts, which have nanosized diameters and micrometer size lengths (Oksman et al. 2006). The lengths of nanowhiskers, which are also recognized as nanocrystals, nanorods or rod-like cellulose microcrystals, range between $500 \mathrm{~nm}-2 \mu \mathrm{m}, 8-20 \mathrm{~nm}$ or less in diameter providing high aspect ratios (de Souza Lima and Borsali 2004). The cellulose crystals had about $150 \mathrm{GPa}$ of modulus and $10 \mathrm{GPa}$ of strength, thus suggesting the potential use of cellulose instead of carbon nanotubes (Helbert et al. 1996). The moisture resistance of biobased polymers has also been improved by cellulose 
nanoreinforcements (Paralikar et al. 2008; Sanchez-Garcia et al. 2008b; Svagan et al. 2009). The improvement in the barrier performance is related to the increase in the tortuosity that leads to slower diffusion and lower WVP values (SanchezGarcia et al. 2008b). Nanosized cellulose fibrils have also a potential to improve the thermal properties of biobased polymers (Helbert et al. 1996; Oksman et al. 2006; Petersson and Oksman 2006).

Starch nanocrystals are one of the distinguished polysaccharide-based nanofillers, which have been shown to improve the mechanical properties of biobased polymers when incorporated up to a $10 \mathrm{wt}$.\% content (Aldao et al. 2018; Villa et al. 2019). The native starch granules are hydrolyzed below the gelatinization temperature to separate the crystalline lamellae, which are more resistant to hydrolysis (Azeredo 2009). The crystalline starch particles generally have a thickness of 6-8 nm and show a platelet morphology (Kristo and Biliaderis 2007).

Chitin whiskers or Cs NPs have been used successfully to improve mechanical strength and barrier performance. Cs NPs have also improved thermo stability and reduced affinity with water when used in the nanocomposite formulations (Antoniou et al. 2015). Cs NPs can be produced by ionic gelation. In this technique, the positively charged amino groups of $\mathrm{Cs}$, interact electrostatically with crosslinking polyanions such as tripolyphosphate (López-León et al. 2005).

\subsection{Processing Techniques for Biobased Nanocomposites}

The biobased nanocomposites are obtained by incorporating nano-fillers into the biobased polymer matrices providing a considerable improvement of the mechanical, barrier, thermal and biodegradation properties of the films due to the favorable interactions between the polymer and the nano-filler (Xie et al. 2013). Three thermodynamically viable structures can be formed for these systems: phase separated (tactoid), intercalated or exfoliated (Ojijo and Sinha Ray 2013) as mentioned previously (see sect. 6.3 - Nanoreinforcement). The desired performance of the nanocomposite is influenced by many factors such as the fillers' spatial arrangement, the morphology of the final product (polymer with nano-filler), the distribution of nanofiller through the polymer matrix and the interfacial interactions between filler and polymer (Unalan et al. 2014). Although several strategies have been applied to develop biobased nanocomposites, the three most commonly used techniques are the following: (1) in-situ polymerization, (2) melt processing or (3) solution casting is mostly adopted (Alexandre and Dubois 2000). In addition, other preparation techniques, such as roll milling, high shear mixing, micro pattern approaches, using supercritical conditions and sonication have gained interest lately. In the following sections, we will focus on three main synthesis approaches and recent techniques to form biobased nanocomposites. 


\subsubsection{In-Situ Polymerization}

In-situ polymerization method includes the polymerization of monomers in the presence of the layered materials to begin the polymer formation (Unalan et al. 2014). First, the nano-fillers are swollen in a monomer solution, and then the polymerization is initiated by different polymerization techniques such as a suitable catalyst or organic initiator, diffusion, heat or radiation applications before the swelling of the monomer (Koo 2006). The main disadvantage of this method is the phase separation or sedimentation that may occur depending on the incompatible structure of the organic polymer (proteins and polysaccharides) and the fillers (Chivrac et al. 2009). To overcome the problems of phase separation, the interaction between the polymer solution and the filler is improved to stabilize the nanoparticle dispersions by linking specific groups onto their surface (Althues et al. 2007).

\subsubsection{Melt Processing}

Melt processing is commonly used for thermoplastic polymers and is considered economically viable and 'green' (solvent-free) techniques (Armentano et al. 2018). In the melt processing method, the nano-fillers are incorporated into the molten polymer, while being heated statically or under shear (Vaia et al. 1996; Vaia and Giannelis 1997). The solvent-free structure (especially organic solvents) and compatibility with existing industrial processes (e.g. extrusion and injection molding, etc.) make melt mixing process more advantageous compared to in-situ polymerization or solution-based techniques (Gutiérrez and Alvarez 2017b,c,d). In addition, the melt intercalation can be used for the biopolymers that are not suitable for insitu polymerization.

Two main factors that control the level of dispersion of the nano-fillers within the polymer matrix throughout the melt processing are: (1) enthalpy-driven interaction between the polymer and the nano-filler, and (2) processing conditions (Ojijo and Sinha Ray 2013). The polymer must be adequately compatible with nano-filler surface and there must be adequate enthalpic interaction between them to ensure a favorable dispersion. The interaction between the NPs and the polymer depends on the diffusion of polymer chains from the molten bulk through the filler layers, which in turn effects the formation of biobased nanocomposites (Vaia and Giannelis 1997).

For the formation of biobased nanocomposites, the melt processing method has a disadvantage, which is the polymer degradation due to the high temperature and mechanical shear force. The processing instability results in the segmentation of polymer chains with a reduction of molecular weight due to the thermal, oxidative and hydrolytic degradations that occurs during processing. Therefore, the processing parameters should be optimized for the heat sensitive biobased polymers. 


\subsubsection{Solution Based Approaches: Wet Chemistry}

Solution-based techniques are often preferred instead of melt mixing methods to develop biobased nanocomposites since the thermal degradation temperatures of biobased polymers are lower than their $\mathrm{T}_{\mathrm{g}}$ (Xiong et al. 2018). These techniques are influenced by the physicochemical properties of the biomaterial solutions, and the following points must be taken into account: the selection of the solvent, the polymer concentration/solvent ratio, the external conditions such as pressure, temperature, and moisture during the solvent evaporation (Armentano et al. 2018). In this method, the selected polymer is dissolved in an appropriate solvent and then the dispersed nano-fillers (in the same or a different solvent) are mixed with the polymer solution to form a homogeneous dispersion. The choice of the suitable solvent provides a rapid exfoliation of the filler and the consecutive addition of polymer solution to the dispersed nano-fillers provides a strong interaction between them. Once the polymer chains are intercalated, the solvent within the interlayer of the filler is displaced and adsorbed onto the surface. The driving force to intercalate the biobased polymer into nano-filler layers from a solution is the entropy gained by desorption of the solvent molecules (Ojijo and Sinha Ray 2013). After evaporation of the solvent, the final intercalated structure executes a desired nanocomposite structure (Ojijo and Sinha Ray 2013). The frequently used solution based approaches include layer-by-layer (LbL) assembly, fiber spinning techniques, one-pot approaches and emulsion polymerization ( $\mathrm{Li}$ et al. 2015; Wang et al. 2017; Xiong et al. 2018; Valencia et al. 2019).

The LbL assembly is used to prepare thin multilayers and coatings that allow the control of the distribution, thickness and components of biomolecules in a single layer with the help of interactions taking place at the interface, such as hydrogen bonding, hydrophobic-hydrophobic interactions and electrostatic interactions (Ding et al. 2017; Xiong et al. 2018; Valencia et al. 2019). A wide variety of biobased nanocomponents can be assembled into different biobased polymers through specific deposition techniques such as spray coating, spin coating and immersive/dipcoating (Richardson et al. 2015). These systems also allow the $\mathrm{pH}$ control to regulate the behavior of NPs into the polymer matrix.

One-pot directed assembly includes cast drying and vacuum-assisted filtration techniques, which require a homogeneous mixture of the biopolymer solution and nano-filler dispersion (Wang et al. 2014). In the vacuum-assisted filtration technique, the colloidal mixture of polymer solution and nano-filler dispersion is passed through a nano-sized pore filter while avoiding the aggregation of these nano-fillers with bonded biopolymers in the upper layer. In the solution-casting technique, the final film solution is poured into the dishes or poured on the different surfaces with different methods, such as spraying or bar coating to fabricate layered films after solvent removal (Xiong et al. 2018). Both techniques produce biobased nanocomposites with high compatibility, homogeneity and improved properties compared to LbL (Hu and Tsukruk 2015). 
Spinning techniques: wet spinning and electrospinning are conventional methods to obtain biobased nanocomposite fibers (Yan et al. 2010; García-Moreno et al. 2018). Wet spinning is suitable to produce large-scale biobased microfibers, while electrospinning produces extremely fine and specifically aligned nanofibers which can be used as a matrix or nanoreinforcement. Similar to the solution intercalation technique, the polymer nanocomposites are produced after dispersion of layered silicate in the aqueous phase (Koo 2006).

\subsubsection{High Shear Mixing and Roll Milling}

The solid or liquid nano-fillers are mixed with the polymer solution using a highshear equipment to prevent the aggregation of nano-fillers and disperse the polymer chains through the nano-filler layers. If the surface treated NPs are compatible with the selected polymer, an intercalated or exfoliated nanocomposite structure will be formed. Roll milling is another shear mixing technique which requires less shear stress compared to the high shear mixing technique. In this method, all components are mixed at room temperature based on shear to disruption of van der Waals interactions between layers (Sorrentino et al. 2005; Guo and Chen 2014). The energy transfer between the mills and the mixture of nanocomposites not only promotes the mixing and dispersion of the filler, but also maintains the intrinsic structure of the newly obtained layers.

\subsubsection{Other Methods}

Freeze-drying is a dehydration process, which is used by freezing biobased nanocomposites in a solution or hydrogel (Rey and May 2010). This technique produces highly porous and ultralight weight bionanocomposite aerogels with respect to the preservation of the structure of nanocomposites in the wet state. The capillary forceinduced collapse of the nanopores is prevented even when the sublimation of the surrounding small molecular solvents. The distribution and orientation of the aerogels, as well as their pore size and shape, are controlled during the freeze-drying process (Lorenzo et al. 2018; Patel 2018).

Micro-patterned biobased nanocomposites produce 2D or 3D organized morphologies showing comprehensive physical properties and an unusual distribution of the components. Micro-patterns provide a way to adaptive behavior, such as selfrolling, self-folding, and actuation. The pattern strategies to form biobased nanocomposites include mainly mask-based patterning, ink-jet printing, and 3D/4D printing (Sun et al. 2018; Xiong et al. 2018).

The sonication has gained attention to the generation of novel NPs (Gutiérrez and Álvarez 2017a; Gutiérrez 2018f). Sonication includes the deagglomeration and reduction of micro-sized particles such as tactoids by the application of sound 
waves. This is achieved due to the cavitation effect, which is the formation, growth, and the collapse of bubbles in a liquid (Hielscher 2005; Gutiérrez and Álvarez 2017a). After the collapse of the bubbles, several important local events accelerate deagglomeration of dispersed micro-sized particles. The acoustic cavitation helps form unique materials at room-temperature liquid in contrast to the extreme conditions such as high pressures and temperatures, or a longer reaction period than that required in the conventional methods. The ultrasonication was first adopted to manufacture polymer nanocomposites based on petroleum-derived polymer/inorganic clay systems, and was then gradually extended to biobased nanocomposites (e.g. polysaccharides, proteins and lipids) (Feng et al. 2014; Soheilmoghaddam et al. 2014).

As another processing method, the sol-gel process is a synthesis process that contains in the preparation of a sol, successive gelation and solvent removal. In these systems, the sol (colloidal solution) acts as a precursor and the gel (threedimensional polymeric network) is formed from hydrolysis, followed by polycondensation (Vartiainen et al. 2014).

\subsection{Properties of Polymer Nanocomposites}

The mechanical, barrier, optical, thermal and functional (i.e. antimicrobial, antioxidant) performance of nanocomposites are the most important parameters for food packaging applications. The properties of biobased nanocomposites depend on their microstructure related to their high aspect ratio. Substantial improvements in these properties are associated with the degree of crystallinity, presence of amorphous phase, polar or apolar groups into the polymer, degree of crosslinking, $\mathrm{T}_{\mathrm{g}}$ and pretreatments (Galić and Ciković 2003). This section presents the main properties that can be improved by incorporating fillers.

\subsubsection{Barrier Properties}

The quality of a food product is exposed to continuous change due to the transfer of water vapor and oxygen through the wall of the polymer package (Gagnard et al. 2004). The type and size of the nano-fillers and the structure of the nanocomposites influence the degree of improvement in the barrier performance of nanocomposites (Shankar and Rhim 2016a). The reason for such improvement is the presence of highly dispersed nano-fillers that form an impermeable structure to the molecules in the polymer matrix due to the their high aspect ratio (Xu et al. 2006; Choudalakis and Gotsis 2009). The permeant molecules are forced to travel through a tortuous pathway within the polymer composite, thus increasing the length of the diffusion path (Gutiérrez and Álvarez 2017b; Tapia-Blácido et al. 2018). The barrier properties are also influenced by the size, shape, and polarity of the penetrating molecule 
and crystallinity, the degree of crosslinking and polymer chain (Pillai and SinhaRay 2015). For example, a higher degree of polymer crystallinity decreases the rate of gas transmission, because the crystallites do not allow the gas molecules to permeate through the polymer, while the amorphous regions limit the permeation through the semicrystalline polymers (Siracusa 2012). In addition, platelet-shape fillers show better permeability performances than fillers more compact shaped (Duncan 2011). In contrast, some nano-fillers cause an increase in the permeability when the polymer does not wet the filler.

\subsubsection{Mechanical Properties}

The purpose of the packaging is to protect the food from undesirable external influences and deficiencies such as random breaks and cracks in the material (Zeman 2007). The mechanical properties of a biobased polymer, such as $E$, maximum stress $\left(\sigma_{\max }\right)$, strain at break $\left(\varepsilon_{b}\right)$ and tenacity $(T)$, should be improved for food packaging applications. The formation of biobased nanocomposites with fillers has the potential to obtain excellent mechanical properties when low levels of filler $(<5 \mathrm{wt} . \%)$ are incorporated. The mechanical performance of the nanocomposites depends on the concentration, shape, size and orientation of the fillers (Youssef 2013). Such improvement in mechanical properties can be attributed to the high aspect ratio of nano-fillers and their stiffness, which in turn changes the mobility and the relaxation behavior of molecules (Azizi Samir et al. 2005). A good adhesion at the filler-polymer interface increases the $E$ and $\sigma_{\max }$ values and heat resistance, while improving the shear resistance, exfoliation and corrosion resistance (Hussain et al. 2006).

\subsubsection{Optical Properties}

The optical properties of food packaging films, such as light transmission, exhibition of color and surface brightness, are important for the stability of the shelf life of packaged foods, as well as for consumer satisfaction (Robertson 2013). The transparency and UV-light barrier properties of polymer nanocomposites are the most important parameters along with their clarity, haze, color, brightness and refractive index. Biobased nanocomposite systems providing UV-barrier properties by adding metals and their oxides (i.e. $\mathrm{Ag}, \mathrm{Al}_{2} \mathrm{O}_{3}, \mathrm{MgO}, \mathrm{TiO}_{2}, \mathrm{ZnO}$ ) or clays are important (Hsieh et al. 2006; Vartiainen et al. 2010; Du et al. 2012; Kanmani and Rhim 2014). The optical properties of a nanocomposite are dependent on the size, dispersion/distribution, nano-filler concentration and the application techniques. When well-distributed nano-fillers are used, polymer nanocomposites show similar transparency compared to pure polymer matrices, because fillers that are smaller than the visible light wavelength cannot block the light (Fischer 2003). 
The optical properties of the final nanocomposite may be affected due to the inefficient dispersion or distribution of the filler into the polymer matrix or the addition of the filler at high concentrations (Unalan et al. 2014). The incompatibility between biobased polymer and nano-filler leads to an inefficient distribution. On the other hand, the filler volume fraction increases with high concentration of the filler, which leads to a proportional increase in haze due to an increase in the dispersion centers (Introzzi et al. 2012). The optical properties of these nanocomposites can thus be controlled by selecting the appropriate filler and optimal processing conditions, such as the processing period, temperature, energy requirement, concentration of the fillers or other compounds, and the type of solvents. Biobased nanocomposites with adequate transparency and UV-barrier properties are good candidates for coating applications such as wrapping for processed food products, or as multilayer films, and containers (Shankar and Rhim 2016a).

\subsubsection{Thermal Properties}

The thermal stability of biobased polymer is another important aspect to be considered, especially to be able to process at an elevated temperature without degradation. Thermally stable biobased nanocomposites can be synthesized by solution-based methods in aqueous medium, where the final degradation occurs at higher temperature compared to pristine biopolymers. Nano-fillers have a higher $E$ and a lower thermal expansion coefficient compared to the polymers, thus the addition of these fillers provide thermal stability to biobased polymers (Yoon et al. 2002). As a rule, the temperature, types and concentration of nano-filler play an important role on the thermal stability of polymer nanocomposites (Pavlidou and Papaspyrides 2008). There are three steps for decomposition patterns (Swain et al. 2018). In the first step, all materials begin to lose adsorbed water (free water or available water) at about $100{ }^{\circ} \mathrm{C}$. Partial thermal decomposition of the biobased nanocomposite occurs in the second step, while in the third step, it produces the complete decomposition and oxidation. The nano-fillers improve the thermal stability of biobased nanocomposites with two main functions called barrier effect and catalytic effect against the polymer degradation (Zhao et al. 2005). In general, the dispersed crystalline nano-fillers behave as an insulator for heat transfer and a barrier against the diffusion of the volatile compounds formed during thermal decomposition. Nano-fillers increase the thermal stability of the polymer under oxidative conditions through its oxygen barrier properties (Pavlidou and Papaspyrides, 2008).

\subsubsection{Surface Properties}

The incorporation of nano-fillers into biopolymers can also affect the surface properties of the final material. The surface properties have a key role in food packaging applications, such as printing, lamination and co-extrusion. The addition of filler 
can increase the surface roughness depending on the longitudinal distribution of the fillers (Rhim 2011; Gutiérrez and González 2017; Gutiérrez et al. 2018b). Such an increase in surface roughness leads to a increase in the haze of the final material and changes the surface wettability attributes (Peacock and Calhoun, 2012). In addition, the chemical structure of the filler has a great effect on the surface roughness. For example, porous fillers such as zeolites or fillers that have an affinity for water can change the absorption behavior at the solid/liquid interface (Vartiainen et al. 2010). The increase in the roughness, which is described by alterations in the friction coefficient, also depends on the concentration of filler and the type of biobased polymer.

The surface factors of biopolymers can also play an important role in different situations, such as wettability, surface mobility, electrical charge, crystallinity and the modulus associated with various reactions. For example, in response to a hydrophobic environment, molecules with low energy (more hydrophobic) can move to the surface and reduce the interfacial energy. On the other hand, in response to an aqueous environment, the surface can reverse its structure to interact with the polar water molecules (Rastogi and Samyn 2015). The surface properties of biopolymers can thus influence the barrier and mechanical properties. The surface hydrophobicity is sometimes a requirement to obtain a barrier against water vapor and water resistance. The incorporation of low surface energy chemicals or the modification of surface properties by incorporating nano-fillers are the easiest ways to improve the hydrophobicity of an existing surface (Li et al. 2010).

\subsubsection{Functional Properties}

The term 'functional nanocomposite' is generally associated to a polymer or a polymer mixture containing an active nanostructured material, which confers an activity such as antimicrobial activity or oxygen-scavenging capacity, to improve the quality and safety of packaged food products (Rhim et al. 2013). These types of nanocomposites are of great interest due to their active properties, while remaining adequate structural integrity. In addition to being a reinforcing agent, nano-fillers can be used as carriers of functional additives, such as antimicrobials, antioxidants, minerals, probiotics and vitamins, and can also be used in controlled release from packaging materials through encapsulating them (Honarvar et al. 2016; Gutiérrez 2017b). The functional properties of nanocomposites for food packaging applications are summarized in Fig. 6.3. Biobased polymers enriched with nano-fillers such as $\mathrm{Ag}, \mathrm{ZnO}$, $\mathrm{TiO}_{2}$ and magnesium oxide have the potential to inhibit various microorganisms and can retard the oxidation (Huang et al. 2015). Nano-Ag has been accepted as one of the most powerful agents showing intense toxicity for a wide variety of microorganisms (Kanmani and Rhim 2014). The proposed mechanism for Ag activity includes the interaction of Ag NPs with phosphorus and sulfur-containing proteins to prevent DNA replication, followed by cell death (Kanmani and Rhim 2014). Nano-fillers readily adhere to a wide range of biological molecules with respect to high surface-to-volume ratio, thus improving the effectiveness of these molecules when exposed to the substance on which it is required to act (Honarvar et al. 2016). 


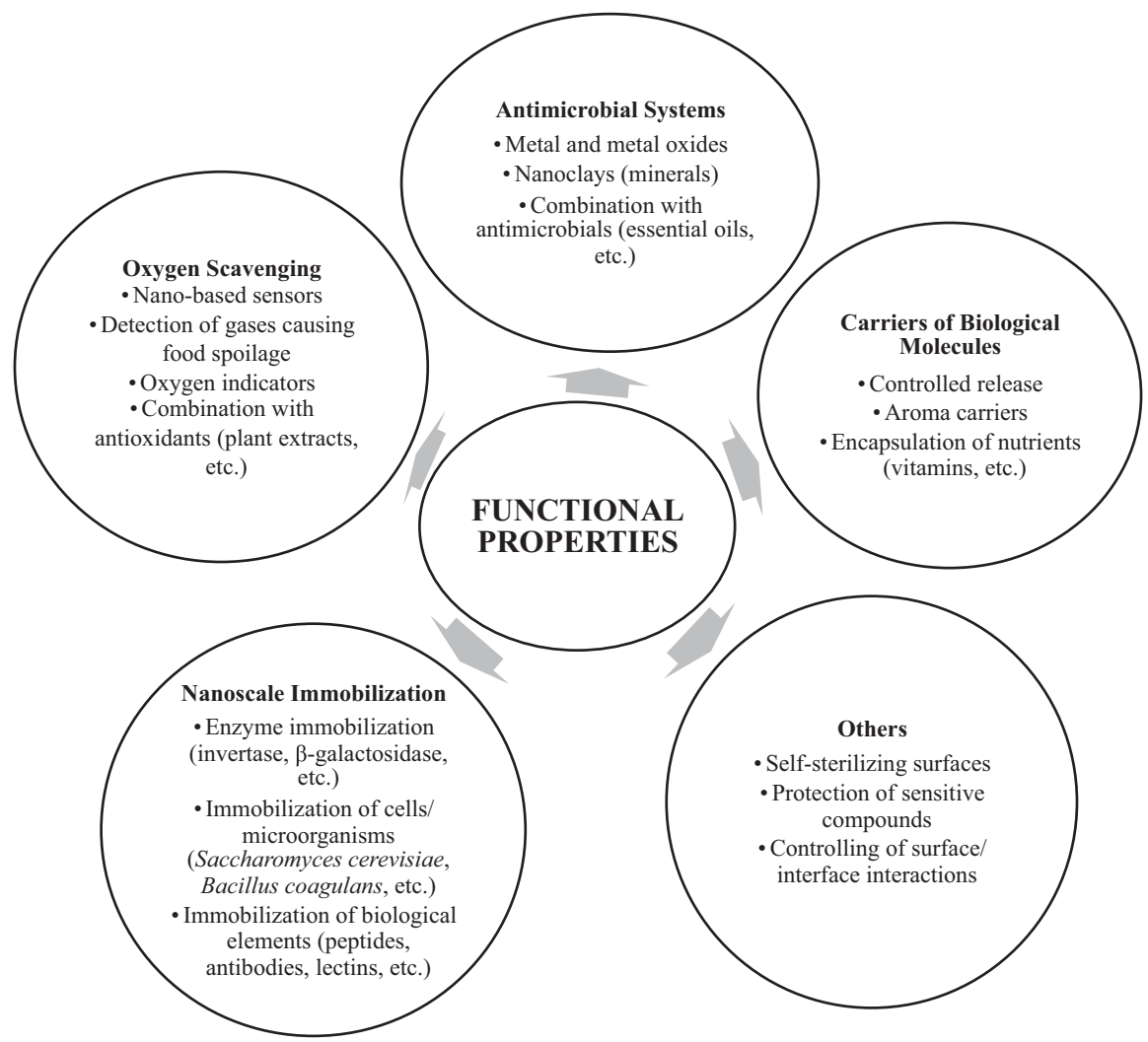

Fig. 6.3 Functional properties of nanocomposites

In addition, antioxidant nanocomposites limit or prevent the lipid oxidation by donating electrons or hydrogen, quenching oxygen and/or scavenging free radicals. The immobilization of enzymes (Chang and Juang 2005), the formation of selfsterilizing polymer surface (Loher et al. 2008), the control of surface/interface interactions (Sanchez et al. 2005) and the protection of sensitive compounds are other functional properties of nanocomposites.

\subsection{Food Packaging Applications}

The nanomaterials are incorporated into the formulation of composite films from biomass in order to improve their mechanical strength, water/gas or lipid barrier properties and provide antimicrobial and anti-browning activities. The current literature is mainly focused on two main groups of nanomaterials, namely (1) the incorporation of nanocellulose and nanoclays (laponite, Mt, modified-Mt, talc, etc.) into nanocomposite film formulations to improve the functional properties, and (2) 
the use of several matrices such as polysaccharides, proteins, lipids, biobased or fossil-based bioplastics (polycaprolactone - PCL, polyvinyl alcohol - PVA, PLA, etc.) acting as a host to these nanomaterials (Lee et al. 2009; De Mesquita et al. 2010; Gutiérrez and Alvarez 2017e; Alvarado et al. 2018; Gutiérrez 2018g; Niu et al. 2018).

Cellulose-containing composite films and their characterization methods are summarized in Table 6.1. As shown in the table, the amount of cellulose nanomaterial in the composite films is generally between 1 to $10 \%$, but the formation of composite films with extreme levels of nanocellulose is also tested up to $100 \%$. These materials are frequently evaluated in terms of their chemical, mechanical, optical, physical and thermal properties.

The mechanical strength of nanocomposite films depends on the matrix of the composite, the source of nanocellulosic material, the production methods of nanocellulose, the addition of other minor constituents to form the film (plasticizer etc.) and the amount of nanocellulose that is incorporated into the film (Khan et al. 2014; Ilyas et al. 2018; Vilarinho et al. 2018). Kwak et al. (2018) studied the effects of bamboo-derived cellulose nanofibers on the nanocomposite film properties composed of silk sericin using glycerin as a plasticizer. They concluded that the $\sigma_{\max }$ of the films increased from 9.47 MPa (without cellulose nanofiber) to a maximum of 28.20 MPa with the addition of $10 \%$ cellulose nanofiber, while the $E$ of the films increased from $320.42 \mathrm{MPa}$ (control) to $805.96 \mathrm{MPa}$ for $20 \%$ nanocellulosecontaining films (Kwak et al. 2018). However, $\varepsilon_{\mathrm{b}}$ values decreased linearly with respect to the increase in the amount of cellulose (Kwak et al. 2018). Similarly, the addition of nanocellulose to agar-based composite films increased the $\sigma_{\max }$ and $E$ values in the films containing up to $3 \%$ filler, and the $\varepsilon_{\mathrm{b}}$ value of composite film containing 5\% nanocellulose was higher than the other cellulose levels (Shankar and Rhim 2016b). Shankar and Rhim (2016b) also studied the effect of incorporating microcrystalline cellulose at the same levels of nanocellulose, and the $\sigma_{\max }, \varepsilon_{\mathrm{b}}$ and $E$ values of these films were comparably lower than nanocellulose-containing films and even lower than the control film. As an extreme condition, Robles et al. (2016) studied on the composite films made from cellulose nanofibers (90-100\%) containing chitin nanocrystals between $0-10 \%$. The $\sigma_{\max }$ and $E$ values did not vary significantly with the increasing amount of cellulose nanofiber, although the highest $\varepsilon_{\mathrm{b}}(7.57 \%)$ value belonged to the $100 \%$ cellulose nanofiber film (Robles et al. 2016). Ilyas et al. (2018) produced a nanocomposite film containing lowest level of cellulose $(0-1 \%)$ using sugar palm starch and sugar palm nanocellulose. The incorporation of nanocellulose improved the $\sigma_{\max }$ and $E$ values up to a $0.5 \%$ content, although the $1 \%$ nanocellulose did not have a similar behavior due to the uneven distribution and agglomeration of the nanocellulose (Ilyas et al. 2018). In addition, the addition of sugar palm nanocellulose reduced the $\varepsilon_{\mathrm{b}}$ values of the films compared to the control sample (Ilyas et al. 2018).

The mechanical properties are also influenced from the minor constituents that are added for film-forming capacity of nanocellulose-containing composite films. For example, the addition of gum Arabic to nanocellulose/starch composite films resulted in higher $\sigma_{\max }$ and $\varepsilon_{\mathrm{b}}$ values compared to the pure starch and 
Table 6.1 Properties of cellulose-containing nanocomposite films

\begin{tabular}{|c|c|c|c|}
\hline Film materials & $\begin{array}{l}\text { Amount of } \\
\text { nanocellulose } \\
(\%)\end{array}$ & Characterization of films & References \\
\hline PVA-nanocellulose & $1-5$ & $\begin{array}{l}\text { SEM, tensile deformation, TGA } \\
\text { and XRD }\end{array}$ & Lee et al. (2009) \\
\hline $\begin{array}{l}\text { Cs-cellulose } \\
\text { nanowhisker }\end{array}$ & $\begin{array}{l}1 \text { (multiple } \\
\text { layers) }\end{array}$ & $\begin{array}{l}\text { FTIR, SEM, TEM, UV-Vis } \\
\text { spectroscopy and zeta potential }\end{array}$ & $\begin{array}{l}\text { de Mesquita et al. } \\
\text { (2010) }\end{array}$ \\
\hline $\begin{array}{l}\text { Methyl } \\
\text { cellulose- } \\
\text { nanocellulose }\end{array}$ & $0.1-1$ & $\begin{array}{l}\text { DSC, FTIR, puncture strength } \\
\text { and deformation, SEM, TGA, } \\
\text { viscoelasticity, WVP and XRD }\end{array}$ & $\begin{array}{l}\text { Khan et al. } \\
(2010)\end{array}$ \\
\hline $\begin{array}{l}\text { HPMC-nanofibrilate } \\
\text { cellulose/HPMC- } \\
\text { cellulose nanowhisker }\end{array}$ & $\begin{array}{l}2.66-13.33 \text { (of } \\
\text { HPMC) }\end{array}$ & $\begin{array}{l}\text { FESEM, mechanical strength, } \\
\text { SEM, transparency and WVP }\end{array}$ & $\begin{array}{l}\text { Bilbao-Sainz } \\
\text { et al. (2011) }\end{array}$ \\
\hline $\begin{array}{l}\text { Sodium } \\
\text { caseinate- } \\
\text { nanocellulose }\end{array}$ & $1-3$ & $\begin{array}{l}\text { Contact angle, DMA, FTIR, } \\
\text { moisture sorption, opacity, } \\
\text { porosity, SEM, WVP and } \sigma_{\max }\end{array}$ & $\begin{array}{l}\text { Pereda et al. } \\
\text { (2011) }\end{array}$ \\
\hline $\begin{array}{l}\text { Starch-gum } \\
\text { arabic-nanocellulose }\end{array}$ & 1 (of starch) & $\begin{array}{l}\text { Contact angle, FTIR, mechanical } \\
\text { strength, surface topography, } \\
\text { water solubility and WVTR }\end{array}$ & $\begin{array}{l}\text { Vigneshwaran } \\
\text { et al. (2011) }\end{array}$ \\
\hline $\begin{array}{l}\text { к-Carrageenan- } \\
\text { nanofibrillated } \\
\text { cellulose }\end{array}$ & $0.1-1$ & $\begin{array}{l}\text { DSC, mechanical strength, OTR, } \\
\text { SEM, WVTR and XRD }\end{array}$ & $\begin{array}{l}\text { Savadekar et al. } \\
\text { (2012) }\end{array}$ \\
\hline $\begin{array}{l}\text { Alginate-Mt-cellulose } \\
\text { nanoparticle }\end{array}$ & $1-5$ (of solid) & $\begin{array}{l}\text { Contact angle, DSC, mechanical } \\
\text { strength, opacity, SEM, water } \\
\text { solubility, WVP and XRD }\end{array}$ & $\begin{array}{l}\text { Abdollahi et al. } \\
\text { (2013) }\end{array}$ \\
\hline $\begin{array}{l}\text { Cs-olive oil- cellulose } \\
\text { nanocrystal }\end{array}$ & $1-12$ & $\begin{array}{l}\text { Color, contact angle, DMA, } \\
\text { opacity, moisture sorption, WVP } \\
\text { and } \sigma_{\max }\end{array}$ & $\begin{array}{l}\text { Pereda et al. } \\
\text { (2014) }\end{array}$ \\
\hline Agar-nanocellulose & $\begin{array}{l}1-10 \text { (of agar } \\
\text { amount) }\end{array}$ & $\begin{array}{l}\text { Color, contact angle, FESEM, } \\
\text { FTIR, TEM, TGA, transparency, } \\
\text { water solubility, WVP, XRD and } \\
\sigma_{\max }\end{array}$ & $\begin{array}{l}\text { Reddy and Rhim } \\
\text { (2014) }\end{array}$ \\
\hline $\begin{array}{l}\text { PLA-cellulose } \\
\text { nanofiber }\end{array}$ & $0-10$ & FTIR, SEM and WVTR & Song et al. (2014) \\
\hline $\begin{array}{l}\text { Cs-cellulose } \\
\text { nanocrystal }\end{array}$ & $5-15$ & $\begin{array}{l}\text { Contact angle, DSC, FTIR, SEM, } \\
\text { TGA, TMA and XRD }\end{array}$ & $\begin{array}{l}\text { Celebi and Kurt } \\
(2015)\end{array}$ \\
\hline $\begin{array}{l}\text { WPI-cellulose } \\
\text { nanofiber }\end{array}$ & $\begin{array}{l}2.5-7.5 \text { (of } \\
\text { WPI) }\end{array}$ & $\begin{array}{l}\text { FTIR, mechanical strength, SEM, } \\
\text { transparency, water solubility, } \\
\text { WVP and XRD }\end{array}$ & $\begin{array}{l}\text { Qazanfarzadeh } \\
\text { and Kadivar } \\
(2016)\end{array}$ \\
\hline $\begin{array}{l}\text { Chitin nanocrystal- } \\
\text { cellulose nanofiber }\end{array}$ & $90-100$ & $\begin{array}{l}\text { AFM, antifungal activity, contact } \\
\text { angle, DLS, FTIR, mechanical } \\
\text { strength, porosity, SEM, TGA, } \\
\text { WVTR and XRD }\end{array}$ & $\begin{array}{l}\text { Robles et al. } \\
(2016)\end{array}$ \\
\hline $\begin{array}{l}\text { Agar-nanocellulose/ } \\
\text { agar-microcrystalline } \\
\text { cellulose }\end{array}$ & $\begin{array}{l}1-10 \text { (of agar } \\
\text { amount) }\end{array}$ & $\begin{array}{l}\text { Color, contact angle, FTIR, TGA, } \\
\text { transparency, WVP, XRD and } \\
\sigma_{\max }\end{array}$ & $\begin{array}{l}\text { Shankar and } \\
\text { Rhim (2016b) }\end{array}$ \\
\hline
\end{tabular}


Table 6.1 (continued)

\begin{tabular}{l|l|l|l}
\hline Film materials & $\begin{array}{l}\text { Amount of } \\
\text { nanocellulose } \\
(\%)\end{array}$ & Characterization of films & References \\
\hline Cs-cellulose nanofiber & $0-30$ & $\begin{array}{l}\text { Antibacterial activity, FTIR, } \\
\text { mechanical strength, SEM and } \\
\text { transmission }\end{array}$ & $\begin{array}{l}\text { Deng et al. } \\
(2017)\end{array}$ \\
\hline $\begin{array}{l}\text { PLA-PVA-cellulose } \\
\text { nanocrystals }\end{array}$ & 1 (of PLA) & $\begin{array}{l}\text { DSC, FTIR, mechanical strength, } \\
\text { TGA and XRD }\end{array}$ & $\begin{array}{l}\text { Alvarado et al. } \\
\text { (2018) }\end{array}$ \\
\hline $\begin{array}{l}\text { Starch-nanocrystalline } \\
\text { cellulose }\end{array}$ & $0.1-1$ (of & $\begin{array}{l}\text { Compostability, density, DMA, } \\
\text { DSC, FESEM, FTIR, solubility, } \\
\text { TEM, TGA, transmittance, water } \\
\text { absorption, WVP, XRD and } \sigma_{\max }\end{array}$ & Ilyas et al. (2018) \\
\hline $\begin{array}{l}\text { PLA-Cs-cellulose } \\
\text { nanofiber }\end{array}$ & $0-10$ & $\begin{array}{l}\text { Antibacterial activity, FTIR, } \\
\text { mechanical strength, SEM, TEM, } \\
\text { XPS and XRD }\end{array}$ & Niu et al. (2018) \\
\hline
\end{tabular}

AFM: atomic force microscopy, DLS: dynamic light scattering, DMA: dynamic mechanical analysis, DSC: differential scanning calorimetry, FESEM: field emission scanning electron microscopy, FTIR: Fourier transform infrared, HPMC: hydroxypropyl methylcellulose, OTR: oxygen transmission rate, SEM: scanning electron microscopy, TEM: transmission electron microscopy, TGA: thermogravimetric analysis, TMA: thermal mechanical analysis, WPI: whey protein isolate, XPS: $X$-ray photoelectron spectroscopy, XRD: X-ray diffraction

starch/nanocellulose films, and the improvement of $\sigma_{\max }$ and $\varepsilon_{\mathrm{b}}$ values with the incorporation of nanocellulose was more pronounced with respect to the addition of gum Arabic (Vigneshwaran et al. 2011). Qazanfarzadeh and Kadivar (2016) found that $\varepsilon_{\mathrm{b}}$ values of whey protein composite films influenced negatively with the addition of cellulose nanofibers, while the $\varepsilon_{\mathrm{b}}$ values of whey protein-glycerol composite films decreased significantly by the incorporation of oat husk cellulose nanofibers up to $5 \%$, conversely the highest $\sigma_{\max }$ and $E$ value was observed for $5 \%$ cellulose nanofiber-containing composite films (Qazanfarzadeh and Kadivar 2016).

The reduction of WVP and WVTR of nanocomposite films with the incorporation of cellulose nanomaterials reflects the compatibility of the matrix and the filler. The high aspect ratio and the large surface area of nano-fillers creates a tortuous pathway, which leads the gas molecules travelling through a longer way into the composite film, while the water vapor permeance into the film is reduced. This behavior is also observed in the nanocomposite films containing nanocellulose fillers, though there is a limit to the amount of nano-filler. Beyond a certain limit, the cellulose nanomaterials can be aggregated, and uneven distribution can act reversely and raise the WVP. The WVTR of PLA-containing hydrophobic-modified nanocellulose composites melted on paper under two different environmental conditions, namely $23{ }^{\circ} \mathrm{C}-50 \%$ relative humidity $(\mathrm{RH})$ and $38{ }^{\circ} \mathrm{C}-90 \% \mathrm{RH}$ were evaluated by Song et al. (2014). The WVTR of composites stored at $90 \% \mathrm{RH}$ were comparably higher than the films stored at $50 \% \mathrm{RH}$, but the lowest WVTR value was observed for $1 \%$ nanocellulose containing film at a coating amount $40 \mathrm{~g} / \mathrm{m}^{2}$ 
(around $50 \mathrm{~g} / \mathrm{m}^{2} /$ day). In this amount of cellulose, WVTR was similar to the film containing pristine PLA.

The type of cellulose nanomaterial also affects the WVTR values of composite films. Bilbao-Sainz et al. (2011) studied HPMC based films containing nanofibrillated cellulose (NFC), modified nanofibrilated cellulose (NFCt) and cellulose nanowhiskers produced from eucalyptus sulphite wood pulp. No significant difference between the control film and the composite films containing NFC, NFCt and nanowhiskers were observed at a level of $2.66 \%$ (of HPMC), but the lowest WVTR value was obtained for the composite films containing NFCt and nanowhiskers at a level of $13.33 \%$ nanocellulose (of HPMC) (Bilbao-Sainz et al. 2011). When the thicknesses of these films were considered, the lowest WVP belonged to the films containing $2.66 \%$ and $13.33 \%$ nanocellulose whisker added samples due to increased tortuosity.

Qazanfarzadeh and Kadivar (2016) also observed that the amount of nanocellulose in whey protein isolate (WPI)-based nanocomposite films had a significant reduction effect on the level of incorporation of WVP up to 5\%, but no further improvement on water vapor barrier properties was observed at $7.5 \%$ nanocellulose content. These authors stated that the WVP values remained constant at a level greater than $5 \%$ of the nano-fillers. This is due to the agglomeration and non-homogeneous distribution of nanocellulose within the WPI based film, which was also confirmed by SEM images (Qazanfarzadeh and Kadivar 2016). A similar behavior was observed by Reddy and Rhim (2014) for agar-based nanocomposites. The WVP values of the composites decreased significantly containing up to $3 \%$ of the content of cellulose nanocrystals. The WVP improvement was lost above this content, and increased to $1.86 \times 10^{-9} \mathrm{gm} / \mathrm{m}^{2} \mathrm{~Pa}$.s for composite film containing $10 \%$ nanocrystals. The agglomeration behavior was also confirmed by SEM images for 5\% and $10 \%$ cellulose-containing films. Savadekar et al. (2012) also reported that the WVTR for kappa-carrageenan films decreased from $0.0042 \mathrm{~g} / \mathrm{m}^{2} \mathrm{~h}$ to $0.0001 \mathrm{~g} / \mathrm{m}^{2} \mathrm{~h}$ when the amount of nanocellulose filler increased from 0 to $0.5 \%$. However, it had increased to $0.0021 \mathrm{~g} / \mathrm{m}^{2} \mathrm{~h}$ for a nanocellulose content of $1 \%$.

The WVP of composite films are also quite dependent on the different components of the matrix and the nano-fillers. For example, Pereda et al. (2014) incorporated olive oil into nanocellulose-reinforced Cs-based films, which had a comparatively lower WVP than the nanocellulose-reinforced Cs-based films without olive oil. The addition of nanocellulose improved the water vapor barrier properties of Cs composite films, and their combination with $10 \%$ olive oil resulted in a further improvement of the barrier properties (Pereda et al. 2014).

The homogeneous dispersion of nanocellulose can be followed by means of SEM images, which also provide information about the surface roughness of the film. Nanocellulosic materials begin to agglomerate above a certain content, which increases the roughness and has a detrimental effect on the film integrity (Khan et al. 2010; Abdollahi et al. 2013; Celebi and Kurt 2015; Shankar and Rhim 2016b). The agglomerated particles can decrease the transparency, and $\sigma_{\max }$ and strain values of the films, while there is an increase in water vapor transmission and oxygen transmission rates (Savadekar et al. 2012; Reddy and Rhim, 2014; Shankar and 
Rhim, 2016b; Deng et al. 2017; Kwak et al. 2018; Niu et al. 2018). One option to solve this is the incorporation of plasticizers or stabilizers into composite films or the modification of nanocellulose to promote the dispersion and reduce the agglomeration, so the mechanical and optical properties can also be improved in this way (Bilbao-Sainz et al. 2011; Vigneshwaran et al. 2011; Song et al. 2014).

Mt stands out among the most commonly used nanoreinforcements among biodegradable composites (Avella et al. 2005; Azeredo 2009; Sothornvit et al. 2009; Arora and Padua 2010; Rhim et al. 2013; Kanmani and Rhim 2014; Azevedo et al. 2015). However, other types of clays such as laponite or hectorite have also been used as nanocomposites (Doblhofer et al. 2016; Valencia et al. 2018). The processing capacity, the low cost and the availability make the Mt a good candidate as a nanoreinforcing agent (Azeredo 2009; Souza et al. 2012; Kanmani and Rhim 2014). However, exfoliated structure is necessary for the formation of improved barrier properties, and as explained in Nielsen's theory, homogeneously distributed clay sheets create a longer and more tortuous pathway which makes gas transfer difficult (Azeredo 2009; Arora and Padua 2010). As shown in Table 6.2, the gas and water vapor barrier properties of nanocomposite films are improved with the increasing amounts of Mt. Although above a critical limit, the homogeneity of the clay within the matrix is destroyed and no further improvement in the barrier properties is observed (Tunc et al. 2007; Luecha et al. 2010; Alboofetileh et al. 2013). In some cases, the amount of clay is kept constant and the effect of other ingredients such as plasticizers and metal/metal oxide NPs are evaluated, or nanocomposites are compared with the pure matrices or commercial polymers (Sothornvit et al. 2009; Souza et al. 2012; Heydari et al. 2013; Kanmani and Rhim 2014; Doblhofer et al. 2016). Doblhofer et al. (2016) found that bionanocomposites composed of silk spidroin and $\mathrm{Na}$-hectorite had better water vapor and oxygen barrier properties compared to the commercial PET and EVOH films, respectively (Doblhofer et al. 2016). In contrast to other protein-based nanocomposites, the spidroin-hectorite nanocomposites were not sensitive to the relative humidity variations. López et al. (2015) incorporated talc NPs into TPS-based thermo-sealed packages, resulting in materials with better water vapor and oxygen barrier properties.

These authors also tested the packaging performance during the storage of cherry tomatoes and observed that the sealing of the packages with talc NPs was better than pure TPS.

In order to improve the $\sigma_{\max }$ and $\varepsilon_{b}$ values, glycerol can be added as a plasticizer into the nanocomposites containing clay NPs (Souza et al. 2012; Heydari et al. 2013). However, the improvement in mechanical properties is insignificant, since the water vapor and oxygen vapor barrier properties are destroyed with the increase in the glycerol content (Souza et al. 2012).

The transparency of nanocomposite films due to the incorporation of clay NPs remains constant or decreased significantly (Luecha et al. 2010; Abdollahi et al. 2013; Heydari et al. 2013; Kanmani and Rhim, 2014; Rhim and Wang, 2014; Zolfi et al. 2014; Doblhofer et al. 2016). The reduction in transparency is attributed to the blocking of light transmission by NPs (Kanmani and Rhim 2014; Rhim and Wang 2014). Nonetheless, the addition of plasticizers such as glycerol can improve the transparency of the nanocomposites containing clay NPs (Heydari et al. 2013). 
Table 6.2 Properties of clay nanoparticle-containing composite films

\begin{tabular}{|c|c|c|c|}
\hline Film materials & $\begin{array}{l}\text { Clay amount } \\
(\%)\end{array}$ & Effect of clay on film properties & References \\
\hline $\begin{array}{l}\text { Potato starch-PE-Mt } \\
\text { NPs }\end{array}$ & $0-4$ & $\begin{array}{l}E \text { and } \sigma_{\max } \text { increased, } \mathrm{M} \text { unchanged and } \mathrm{S} \\
\text { was homogeneous }\end{array}$ & $\begin{array}{l}\text { Avella et al. } \\
(2005)\end{array}$ \\
\hline Wheat gluten-Mt & $\begin{array}{l}0-10 \text { (of } \\
\text { gluten) }\end{array}$ & $\begin{array}{l}\text { CA, WA, WVA and } \varepsilon_{b} \% \text { decreased, CP } \\
\text { and OP constant, DT increased for } 5 \% \\
\text { and } 10 \% \mathrm{Mt}, E \text { and } \sigma_{\max } \text { increased, and } \\
\text { WVP decreased up to } 5 \%\end{array}$ & $\begin{array}{l}\text { Tunc et al. } \\
(2007)\end{array}$ \\
\hline Fish gelatin-Mt NPs & $\begin{array}{l}0-9 \text { (of } \\
\text { gelatin) }\end{array}$ & $\begin{array}{l}\text { OP, WVP and } \varepsilon_{b} \% \text { decreased, } \mathrm{S} \text { was } \\
\text { nonhomogeneous up to } 9 \% \mathrm{Mt} \text {, and } \sigma_{\max } \\
\text { increased }\end{array}$ & $\begin{array}{l}\text { Bae et al. } \\
(2009)\end{array}$ \\
\hline $\begin{array}{l}\text { Soy protein } \\
\text { isolate-Mt NPs }\end{array}$ & $0-15$ & $\begin{array}{l}\mathrm{S} \text { was homogeneous up to } 5 \%, \mathrm{SM}, \mathrm{T}_{\mathrm{g}} \\
\text { and } \sigma_{\max } \text { increased, WVP decreased and } \\
\varepsilon_{b} \% \text { increased up to } 5 \%\end{array}$ & $\begin{array}{l}\text { Kumar et al. } \\
(2010)\end{array}$ \\
\hline Corn zein-Mt NPs & $0-10$ & $\begin{array}{l}\text { DT and } E \text { increased, T constant, WVP } \\
\text { decreased up to } 3 \%, \varepsilon_{b} \% \text { decreased and } \\
\sigma_{\max } \text { increased up to } 5 \% \mathrm{Mt}\end{array}$ & $\begin{array}{l}\text { Luecha et al. } \\
(2010)\end{array}$ \\
\hline $\begin{array}{l}\text { Pullulan-Na-Mt } \\
\text { NPs }\end{array}$ & $0.2-3$ & $\mathrm{H}$ and $\mathrm{R}$ increased, and $\mathrm{OP}$ decreased & $\begin{array}{l}\text { Introzzi et al. } \\
(2012)\end{array}$ \\
\hline $\begin{array}{l}\text { Cassava starch- } \\
\text { invert sugar-Mt NPs }\end{array}$ & $0-0.1$ & GT, OP, WVP and $\sigma_{\max }$ decreased & $\begin{array}{l}\text { Souza et al. } \\
(2012)\end{array}$ \\
\hline $\begin{array}{l}\text { Alginate-Mt- } \\
\text { cellulose NPs }\end{array}$ & $\begin{array}{l}1-5 \text { (of } \\
\text { alginate) }\end{array}$ & $\begin{array}{l}\text { CA, T, WS, WVP, } \varepsilon_{b} \%, \sigma_{\max } \text { and } E \\
\text { decreased }\end{array}$ & $\begin{array}{l}\text { Abdollahi } \\
\text { et al. (2013) }\end{array}$ \\
\hline Alginate-Mt NPs & $\begin{array}{l}1-5 \text { (of } \\
\text { alginate) }\end{array}$ & $\begin{array}{l}\text { CA and } \mathrm{O} \text { increased, WS, WVP and } \varepsilon_{b} \% \\
\text { decreased, and } \sigma_{\max } \text { increased up to } 3 \% \\
\text { Mt }\end{array}$ & $\begin{array}{l}\text { Alboofetileh } \\
\text { et al. (2013) }\end{array}$ \\
\hline Corn starch-Mt NPs & $0-5$ & $\begin{array}{l}\text { AA not observed, CA, } \varepsilon_{b} \%, \sigma_{\max } \text { and } E \\
\text { increased, and T decreased }\end{array}$ & $\begin{array}{l}\text { Heydari et al. } \\
(2013)\end{array}$ \\
\hline $\begin{array}{l}\text { к-Carrageenan- } \\
\text { AgNP/Mt NPs }\end{array}$ & $\begin{array}{l}0-5 \text { (of } \\
\text { carrageenan) }\end{array}$ & $\begin{array}{l}\mathrm{AA}, \mathrm{CA}, \varepsilon_{b} \% \text { and } \sigma_{\max } \text { increased, } \mathrm{S} \text { was } \\
\text { homogeneous, } \mathrm{T} \text { and WVP decreased }\end{array}$ & $\begin{array}{l}\text { Rhim and } \\
\text { Wang (2014) }\end{array}$ \\
\hline $\begin{array}{l}\text { Gelatin-AgNP/Mt } \\
\text { NPs }\end{array}$ & 5 (of gelatin) & $\begin{array}{l}\mathrm{CA} \text { and } \sigma_{\max } \text { increased, } E, \mathrm{~T}, \mathrm{WVP} \text { and } \\
\varepsilon_{b} \% \text { decreased, and } \mathrm{S} \text { was homogeneous }\end{array}$ & $\begin{array}{l}\text { Kanmani and } \\
\text { Rhim (2014) }\end{array}$ \\
\hline $\begin{array}{l}\text { Kefiran- whey } \\
\text { protein-Mt } \\
\text { NPs- nano } \mathrm{TiO}_{2}\end{array}$ & $0-5$ & $\begin{array}{l}E, \mathrm{R} \text { and } \sigma_{\max } \text { increased, } \mathrm{S} \text { was } \\
\text { homogeneous, T was constant, WVP and } \\
\varepsilon_{b} \% \text { decreased }\end{array}$ & $\begin{array}{l}\text { Zolfi et al. } \\
\text { (2014) }\end{array}$ \\
\hline $\begin{array}{l}\text { Whey protein-citric } \\
\text { acid-Mt NPs }\end{array}$ & 0-3 (of whey) & $\begin{array}{l}\text { DT decreased, GT decreased up to } 3 \% \\
\text { Mt, and PS, } \varepsilon_{b} \% \text { and } \sigma_{\max } \text { increased }\end{array}$ & $\begin{array}{l}\text { Azevedo et al. } \\
(2015)\end{array}$ \\
\hline $\begin{array}{l}\text { Silk protein-Na } \\
\text { hectorite }\end{array}$ & 60 & $\begin{array}{l}E \text { and } \sigma_{\max } \text { increased, OTR and WVTR } \\
\text { decreased, S was homogeneous, and T } \\
\text { remained constant }\end{array}$ & $\begin{array}{l}\text { Doblhofer } \\
\text { et al. (2016) }\end{array}$ \\
\hline $\begin{array}{l}\text { Cassava starch- } \\
\text { laponite NPs }\end{array}$ & $\begin{array}{l}0-6 \text { (of } \\
\text { starch) }\end{array}$ & $\begin{array}{l}\mathrm{CA} \text { and } \mathrm{G} \text { decreased, } \mathrm{O} \text { remained } \\
\text { constant and } \mathrm{R} \text { increased }\end{array}$ & $\begin{array}{l}\text { Valencia et al. } \\
\text { (2018) }\end{array}$ \\
\hline
\end{tabular}

AA: antimicrobial activity, AgNP: Ag nanoparticle, CA: contact angle, CP: carbon dioxide permeability, DT: degradation temperature, E: Young's modulus, G: gloss, H: haze, M: migration of metals, Mt: montmorillonite, O: opacity, OP: oxygen permeability, OTR: oxygen transmission rate, PE: polyethylene, PS: puncture strength, R: roughness, S: film structure, SM: storage modulus, T: transparency, $T_{g}$ : glass transition temperature, WA: water absorption, WS: water solubility, WVA: water vapor absorption, WVP: water vapor permeability, WVTR: water vapor transmission rate, $\varepsilon_{b} \%$ : strain at break \%, $\sigma_{\max }$ : maximum stress 
Mt has also limited antimicrobial activity. A bacteriostatic effect against Gram positive bacteria from nanocomposite films based on gelatin, WPI and $\kappa$-carrageenan containing Cloisite 30B (organically modified $\mathrm{Mt}$ ) has been reported in the literature (Sothornvit et al. 2009; Kanmani and Rhim 2014; Rhim and Wang 2014). Although no antibacterial effect was observed from the Cloisite- $\mathrm{Na}^{+}$and Cloisite 20A-reinforced WPI-based films. Similarly, Heydari et al. (2013) did not observe antibacterial activity against Gram positive and Gram negative bacteria (E. coli and S. aureus) for Na-Mt-containing corn starch-based films.

Metal and metal oxide NPs are generally used to function as antimicrobial and UV-blocking agents. In particular, Ag NPs are combined with the clay NPs for their supreme contribution to the mechanical, thermal, optical and antimicrobial improvement in the film structure. Kanmani and Rhim (2014) reported that Ag NPs in gelatin-based films had promising results to inhibit Gram positive and negative strains, however, the antibacterial effect was more pronounced for $\mathrm{Mt}$ and $\mathrm{Ag}$ NP-reinforced films (Kanmani and Rhim 2014). De Moura et al. (2012) found that the size of NPs can also promote the bactericidal effect, such as a smaller NP diameter $(41 \mathrm{~nm})$ in Ag NP-reinforced HPMC films had a better antibacterial effect against $E$. coli and $S$. aureus strains compared to nanocomposites with bigger $(100 \mathrm{~nm})$ Ag NPs (De Moura et al. 2012).

Although these films are produced for food packaging applications, only antimicrobial activity is determined by in vitro methods and only some of them are applied in real food samples. Therefore, these studies lack of information about the compatibility of the nanocomposite films with food, the possible effects on food quality during the shelf-life, production costs and the safety for human consumption. Especially the migration of NPs from the nanocomposites into food matrices should be quantified with appropriate methods in order to assess the risk exposure related to the consumption of that particular food (Huang et al. 2015; Honarvar et al. 2016). Regarding the plastics, the European Commission has established an overall migration limit of $60 \mathrm{mg}$ of material $/ \mathrm{kg}$ of food matrix (or simulant) (Avella et al. 2005; Huang et al. 2015). For those materials that migrate to food matrix and that exhibit potential toxic and hazardous effects, a specific migration limit has been included for each substance in the regulations of European Union (EU) No: 10/2011 entitled: 'Plastic materials and articles intended to come into contact with food'. In this context, the migration of $\mathrm{Fe}, \mathrm{Mg}$ and $\mathrm{Si}$ from nanocomposite packaging material containing Mt was tested by Avella et al. (2005) in both foods (lettuce and spinach) and simulant food (water). The authors demonstrated that these composite packaging films were below the overall migration limit of European legislation and had the potential to be used as a food packaging material (Avella et al. 2005).

\subsection{Conclusions and Remarks}

This chapter presents the production methods, classifications and functional properties of biobased nanocomposites, focusing mainly on polysaccharide, protein and lipid-based polymers containing nanocellulose and nanoclays as reinforcing agents. 
The environmental problems arising from the excessive use of petroleum-based polymers have led to the improvements in biobased plastics to reduce the energy consumption and greenhouse gas emissions in certain applications, such as food packaging. However, most biobased polymers have no compatible properties (water resistance, thermal, mechanical and barrier properties, etc.) compared to the petroleum-based polymers. Due to poor chemical and physical stability, low mechanical properties, poor crystallization kinetics and processing complexity may limit their use on a commercial scale. The nanocomposites are a new class of materials with improved performance properties, therefore, the addition of nano-fillers such as nanoclays, nanocellulose, carbon nanotubes, among others help overcome these inconveniences and modify the biopolymers in a better form with improved functionalities. Biobased biopolymers such as starch, cellulose, corn-derived plastics, whey proteins, gelatin, etc. have been widely studied to fabricate nanocomposites for potential use in food packaging applications. For example, the improvements in barrier properties of biobased polymers against water vapor, aroma compounds, as well as other gases (oxygen, carbon dioxide, etc.) have the potential to extend the shelf life of various food products. In addition, the use of biopolymers instead of petroleum-based polymers will help reduce both the packaging waste leading serious environmental problems and food waste by increasing shelf life. On the other hand, some nano-fillers such as nanoclays, Ag NPs, Ag-zeolite, metal oxides and functional biopolymers such as Cs provide antimicrobial or antioxidant activity, enzyme immobilization and self-sterilizing properties. Further improvements are also needed for biobased nanocomposites to develop an optimal formulation and comply with regulations that refer to the migration of nanomaterials from packaging to food matrix, as well as the reduction of the costs of the biobased nanocomposites.

Conflicts of Interest The authors declare no conflict of interest.

\section{References}

Abdollahi, M., Alboofetileh, M., Rezaei, M., \& Behrooz, R. (2013). Comparing physicomechanical and thermal properties of alginate nanocomposite films reinforced with organic and/or inorganic nanofillers. Food Hydrocolloids, 32(2), 416-424. https://doi.org/10.1016/j. foodhyd.2013.02.006.

Abdul Khalil, H. P. S., Bhat, A. H., \& Ireana Yusra, A. F. (2012). Green composites from sustainable cellulose nanofibrils: A review. Carbohydrate Polymers, 87(2), 963-979. https://doi. org/10.1016/j.carbpol.2011.08.078.

Abugoch, L., Tapia, C., Plasencia, D., Pastor, A., Castro-Mandujano, O., López, L., \& Escalona, V. H. (2016). Shelf-life of fresh blueberries coated with quinoa protein/chitosan/sunflower oil edible film. Journal of the Science of Food and Agriculture, 96(2), 619-626. https://doi. org/10.1002/jsfa.7132.

Adame, D., \& Beall, G. W. (2009). Direct measurement of the constrained polymer region in polyamide/clay nanocomposites and the implications for gas diffusion. Applied Clay Science, 42(3-4), 545-552. https://doi.org/10.1016/j.clay.2008.03.005. 
Alboofetileh, M., Rezaei, M., Hosseini, H., \& Abdollahi, M. (2013). Effect of montmorillonite clay and biopolymer concentration on the physical and mechanical properties of alginate nanocomposite films. Journal of Food Engineering, 117(1), 26-33. https://doi.org/10.1016/j. jfoodeng.2013.01.042.

Aldao, D. C., Šárka, E., Ulbrich, P., \& Menšíková, E. (2018). Starch nanoparticles - Two ways of their preparation. Czech Journal of Food Sciences, 36(2), 133-138. https://doi.org/10.1722 1/371/2017-cjfs.

Alexandre, M., \& Dubois, P. (2000). Polymer-layered silicate nanocomposites: Preparation, properties and uses of a new class of materials. Materials Science and Engineering: R: Reports, 28(1-2), 1-63. https://doi.org/10.1016/S0927-796X(00)00012-7.

Alexandre, B., Langevin, D., Médéric, P., Aubry, T., Couderc, H., Nguyen, Q. T., Saiter, A., \& Marais, S. (2009). Water barrier properties of polyamide 12/montmorillonite nanocomposite membranes: Structure and volume fraction effects. Journal of Membrane Science, 328(1-2), 186-204. https://doi.org/10.1016/j.memsci.2008.12.004.

Althues, H., Henle, J., \& Kaskel, S. (2007). Functional inorganic nanofillers for transparent polymers. Chemical Society Reviews, 36(9), 1454-1465. https://doi.org/10.1039/b608177k.

Alvarado, N., Romero, J., Torres, A., López de Dicastillo, C., Rojas, A., Galotto, M. J., \& Guarda, A. (2018). Supercritical impregnation of thymol in poly(lactic acid) filled with electrospun poly(vinyl alcohol)-cellulose nanocrystals nanofibers: Development an active food packaging material. Journal of Food Engineering, 217, 1-10. https://doi.org/10.1016/j. jfoodeng.2017.08.008.

Álvarez, K., Famá, L., \& Gutiérrez, T. J. (2017). Chapter 12. Physicochemical, antimicrobial and mechanical properties of thermoplastic materials based on biopolymers with application in the food industry. In M. Masuelli \& D. Renard (Eds.), Advances in physicochemical properties of biopolymers: Part 1 (pp. 358-400). EE.UU. ISBN: 978-1-68108-454-1. eISBN: 978-1-68108-453-4, 2017: Bentham Science Publishers. https://doi.org/10.217 4/9781681084534117010015.

Álvarez, K., Alvarez, V. A., \& Gutiérrez, T. J. (2018). Chapter 3. Biopolymer composite materials with antimicrobial effects applied to the food industry. In V. K. Thakur \& M. K. Thakur (Eds.), Functional biopolymers (pp. 57-96). EE.UU. ISBN: 978-3-319-66416-3. eISBN: 978-3-319-66417-0: Editorial Springer International Publishing. https://doi. org/10.1007/978-3-319-66417-0_3.

Ansorena, M. R., Pereda, M., \& Marcovich, N. E. (2018). Edible films. In T. J. Gutiérrez (Ed.), Polymers for food applications (pp. 5-24). Cham: Springer. https://doi. org/10.1007/978-3-319-94625-2_2.

Antoniou, J., Liu, F., Majeed, H., \& Zhong, F. (2015). Characterization of tara gum edible films incorporated with bulk chitosan and chitosan nanoparticles: A comparative study. Food Hydrocolloids, 44, 309-319. https://doi.org/10.1016/j.foodhyd.2014.09.023.

Anyango, J. O., Taylor, J., \& Taylor, J. R. N. (2011). Improvement in water stability and other related functional properties of thin cast kafirin protein films. Journal of Agricultural and Food Chemistry, 59(23), 12674-12682. https://doi.org/10.1021/jf203273y.

Araque, L. M., Alvarez, V. A., \& Gutiérrez, T. J. (2018). Chapter 13. Composite foams made from biodegradable polymers for food packaging applications. In T. J. Gutiérrez (Ed.), Polymers for food applications (pp. 347-355). Cham, Germany. ISBN: 978-3-319-94624-5. eISBN: 978-3-319-94625-2:). Editorial Springer International Publishing. https://doi. org/10.1007/978-3-319-94625-2_13.

Armentano, I., Puglia, D., Luzi, F., Arciola, C., Morena, F., Martino, S., \& Torre, L. (2018). Nanocomposites based on biodegradable polymers. Materials, 11(5), 795. https://doi. org/10.3390/ma11050795.

Arora, A., \& Padua, G. W. (2010). Nanocomposites in food packaging. Journal of Food Science, 75(1), 43-49. https://doi.org/10.1111/j.1750-3841.2009.01456.x. 
Avella, M., De Vlieger, J. J., Errico, M. E., Fischer, S., Vacca, P., \& Volpe, M. G. (2005). Biodegradable starch/clay nanocomposite films for food packaging applications. Food Chemistry, 93(3), 467-474. https://doi.org/10.1016/j.foodchem.2004.10.024.

Azeredo, H. M. C. d. (2009). Nanocomposites for food packaging applications. Food Research International, 42(9), 1240-1253. https://doi.org/10.1016/j.foodres.2009.03.019.

Azeredo, H. M. C., Rosa, M. F., \& Mattoso, L. H. C. (2017). Nanocellulose in bio-based food packaging applications. Industrial Crops and Products, 97, 664-671. https://doi.org/10.1016/j. indcrop.2016.03.013.

Azevedo, V. M., Dias, M. V., Borges, S. V., Costa, A. L. R., Silva, E. K., Medeiros, É. A. A., \& Soares, N. d. F. F. (2015). Development of whey protein isolate bio-nanocomposites: Effect of montmorillonite and citric acid on structural, thermal, morphological and mechanical properties. Food Hydrocolloids, 48, 179-188. https://doi.org/10.1016/j.foodhyd.2015.02.014.

Azizi Samir, M. A. S., Alloin, F., \& Dufresne, A. (2005). Review of recent research into cellulosic whiskers, their properties and their application in nanocomposite field. Biomacromolecules, 6(2), 612-626. https://doi.org/10.1021/bm0493685.

Bae, H. J., Park, H. J., Hong, S. I., Byun, Y. J., Darby, D. O., Kimmel, R. M., \& Whiteside, W. S. (2009). Effect of clay content, homogenization RPM, pH, and ultrasonication on mechanical and barrier properties of fish gelatin/montmorillonite nanocomposite films. $L W T$ Food Science and Technology, 42(6), 1179-1186. https://doi.org/10.1016/j.lwt.2008.12.016.

Baldwin, E. A., Nisperos-Carriedo, M. O., \& Baker, R. A. (1995). Edible coatings for lightly processed fruits and vegetables. Horticulture Science, 30(1), 35-38.

Baur, J., \& Silverman, E. (2007). Challenges and opportunities in multifunctional nanocomposite structures for aerospace applications. MRS Bulletin, 32(4), 328-334. https://doi.org/10.1557/ mrs2007.231.

Bertolini, A. C. (2010). In A. C. Bertolini (Ed.), Starches: Characterization, properties, and applications. CRC Press.

Bilbao-Sainz, C., Bras, J., Williams, T., Sénechal, T., \& Orts, W. (2011). HPMC reinforced with different cellulose nano-particles. Carbohydrate Polymers, 86(4), 1549-1557. https://doi. org/10.1016/j.carbpol.2011.06.060.

Bonilla, J., Atarés, L., Vargas, M., \& Chiralt, A. (2012). Edible films and coatings to prevent the detrimental effect of oxygen on food quality: Possibilities and limitations. Journal of Food Engineering, 110(2), 208-213. https://doi.org/10.1016/j.jfoodeng.2011.05.034.

Bourtoom, T. (2009). Edible protein films: properties enhancement. International Food Research Journal, 16(1), 1-9.

Bracone, M., Merino, D., González, J., Alvarez, V. A., \& Gutiérrez, T. J. (2016). Chapter 6. Nanopackaging from natural fillers and biopolymers for the development of active and intelligent films. In S. Ikram \& S. Ahmed (Eds.), Natural polymers: Derivatives, blends and composites (pp. 119-155). New York. EE.UU: Editorial Nova Science Publishers, Inc. isbn:978-1-63485-831-1.

Brody, A. L., Bugusu, B., Han, J. H., Sand, C. K., \& McHugh, T. H. (2008). Innovative food packaging solutions. Journal of Food Science, 73(8), R107-R116. https://doi. org/10.1111/j.1750-3841.2008.01022.x.

Campos, C. A., Gerschenson, L. N., \& Flores, S. K. (2011). Development of edible films and coatings with antimicrobial activity. Food and Bioprocess Technology, 4(6), 849-875. https://doi. org/10.1007/s11947-010-0434-1.

Cazón, P., Velazquez, G., Ramírez, J. A., \& Vázquez, M. (2017). Polysaccharide-based films and coatings for food packaging: A review. Food Hydrocolloids, 68, 136-148. https://doi. org/10.1016/j.foodhyd.2016.09.009.

Celebi, H., \& Kurt, A. (2015). Effects of processing on the properties of chitosan/cellulose nanocrystal films. Carbohydrate Polymers, 133, 284-293. https://doi.org/10.1016/j. carbpol.2015.07.007. 
Chang, M.-Y., \& Juang, R.-S. (2005). Activities, stabilities, and reaction kinetics of three free and chitosan-clay composite immobilized enzymes. Enzyme and Microbial Technology, 36(1), 75-82. https://doi.org/10.1016/j.enzmictec.2004.06.013.

Chen, C. T., Chen, K. I., Chiang, H. H., Chen, Y. K., \& Cheng, K. C. (2017). Improvement on physical properties of pullulan films by novel cross-linking strategy. Journal of Food Science, 82(1), 108-117. https://doi.org/10.1111/1750-3841.13577.

Chin, I., Thurn-albrecht, T., Kim, H., Russell, T. P., \& Wang, J. (2001). On exfoliation of montmorillonite in epoxy. Polymer, 42(13), 5947-5952. https://doi.org/10.1016/s0032-3861(00)00898-3.

Chivrac, F., Pollet, E., \& Avérous, L. (2009). Progress in nano-biocomposites based on polysaccharides and nanoclays. Materials Science and Engineering: R: Reports, 67(1), 1-17. https:// doi.org/10.1016/j.mser.2009.09.002.

Choudalakis, G., \& Gotsis, A. D. (2009). Permeability of polymer/clay nanocomposites: A review. European Polymer Journal, 45(4), 967-984. https://doi.org/10.1016/j.eurpolymj.2009.01.027.

Cirillo, G., Sipizzirri, U. G., \& Iemma, F. (2015). In G. Cirillo, U. G. Sipizzirri, \& F. Iemma (Eds.), Functional polymers in food science: From technology to biology, Volume 1: Food packaging. Wiley. https://doi.org/10.1002/9781119109785.

Cyras, V. P., Manfredi, L. B., Ton-That, M. T., \& Vázquez, A. (2008). Physical and mechanical properties of thermoplastic starch/montmorillonite nanocomposite films. Carbohydrate Polymers, 73(1), 55-63. https://doi.org/10.1016/j.carbpol.2007.11.014.

Dallas, P., Sharma, V. K., \& Zboril, R. (2011). Silver polymeric nanocomposites as advanced antimicrobial agents: Classification, synthetic paths, applications, and perspectives. Advances in Colloid and Interface Science, 166(1-2), 119-135. https://doi.org/10.1016/j.cis.2011.05.008.

De Mesquita, J. P., Donnici, C. L., \& Pereira, F. V. (2010). Biobased nanocomposites from layer-by-layer assembly of cellulose nanowhiskers with chitosan. Biomacromolecules, 11(2), 473-480. https://doi.org/10.1021/bm9011985.

De Moura, M. R., Mattoso, L. H. C., \& Zucolotto, V. (2012). Development of cellulose-based bactericidal nanocomposites containing silver nanoparticles and their use as active food packaging. Journal of Food Engineering, 109(3), 520-524. https://doi.org/10.1016/j. jfoodeng.2011.10.030.

de Souza Lima, M. M., \& Borsali, R. (2004). Rodlike cellulose microcrystals: Structure, properties, and applications. Macromolecular Rapid Communications, 25(7), 771-787. https://doi. org/10.1002/marc.200300268.

Debeaufort, F., Quezada Gallo, J. A., Delporte, B., \& Voilley, A. (2000). Lipid hydrophobicity and physical state effects on the properties of bilayer edible films. Journal of Membrane Science, 180(1), 47-55. https://doi.org/10.1016/s0376-7388(00)00531-7.

Deng, Z., Jung, J., \& Zhao, Y. (2017). Development, characterization, and validation of chitosan adsorbed cellulose nanofiber (CNF) films as water resistant and antibacterial food contact packaging. LWT - Food Science and Technology, 83, 132-140. https://doi.org/10.1016/j. lwt.2017.05.013.

Ding, F., Liu, J., Zeng, S., Xia, Y., Wells, K. M., Nieh, M.-P., \& Sun, L. (2017). Biomimetic nanocoatings with exceptional mechanical, barrier, and flame-retardant properties from large-scale one-step coassembly. Science Advances, 3(7), e1701212. https://doi.org/10.1126/ sciadv. 1701212.

Doblhofer, E., Schmid, J., Rieß, M., Daab, M., Suntinger, M., Habel, C., Bargel, H., Hugenschmidt, C., Rosenfeldt, S., Breu, J., \& Scheibel, T. (2016). Structural insights into water-based spider silk protein-nanoclay composites with excellent gas and water vapor barrier properties. ACS Applied Materials and Interfaces, 8(38), 25535-25543. https://doi.org/10.1021/ acsami.6b08287.

Du, M., Guo, B., \& Jia, D. (2010). Newly emerging applications of halloysite nanotubes: A review. Polymer International, 59(5), 574-582. https://doi.org/10.1002/pi.2754.

Du, Q. G., Alagappan, G., Dai, H., Demir, H. V., Yu, H. Y., Sun, X. W., \& Kam, C. H. (2012). UV-blocking ZnO nanostructure anti-reflective coatings. Optics Communications, 285(13-14), 3238-3241. https://doi.org/10.1016/j.optcom.2012.02.095. 
Duncan, T. V. (2011). Applications of nanotechnology in food packaging and food safety: Barrier materials, antimicrobials and sensors. Journal of Colloid and Interface Science, 363(1), 1-24. https://doi.org/10.1016/j.jcis.2011.07.017.

Egger, S., Lehmann, R. P., Height, M. J., Loessner, M. J., \& Schuppler, M. (2009). Antimicrobial properties of a novel silver-silica nanocomposite material. Applied and Environmental Microbiology, 75(9), 2973-2976. https://doi.org/10.1128/AEM.01658-08.

Elsabee, M. Z., \& Abdou, E. S. (2013). Chitosan based edible films and coatings: A review. Materials Science and Engineering C, 33(4), 1819-1841. https://doi.org/10.1016/j.msec.2013.01.010.

European Bioplastics. (2018). Bioplastics market data. Retrieved February 28, 2019, from https:// www.european-bioplastics.org/market/

Falguera, V., Quintero, J. P., Jiménez, A., Muñoz, J. A., \& Ibarz, A. (2011). Edible films and coatings: Structures, active functions and trends in their use. Trends in Food Science and Technology, 22(6), 292-303. https://doi.org/10.1016/j.tifs.2011.02.004.

Feng, X., Wang, X., Xing, W., Zhou, K., Song, L., \& Hu, Y. (2014). Liquid-exfoliated MoS 2 by chitosan and enhanced mechanical and thermal properties of chitosan/MoS $\mathrm{S}_{2}$ composites. Composites Science and Technology, 93, 76-82. https://doi.org/10.1016/j.compscitech.2013.11.016.

Fernández, A., Soriano, E., Hernández-Muñoz, P., \& Gavara, R. (2010). Migration of antimicrobial silver from composites of polylactide with silver zeolites. Journal of Food Science, 75(3), E186-E193. https://doi.org/10.1111/j.1750-3841.2010.01549.x.

Fischer, H. (2003). Polymer nanocomposites: From fundamental research to specific applications. Materials Science and Engineering: C, 23(6-8), 763-772. https://doi.org/10.1016/j. msec.2003.09.148.

Forano, C., Hibino, T., Leroux, F., \& Taviot-Guého, C. (2006). Layered double hydroxides. In F. Bergaya, B. K. G. Theng, \& G. Lagaly (Eds.), Developments in clay science (pp. 1021-1095). Elsevier. https://doi.org/10.1016/s1572-4352(05)01039-1.

Gagnard, C., Germain, Y., Keraudren, P., \& Barrière, B. (2004). Permeability of semicrystalline polymers to toluene/methanol mixture. Journal of Applied Polymer Science, 92(1), 676-682. https://doi.org/10.1002/app.20184.

Galić, K., \& Ciković, N. (2003). The effect of liquid absorption on gas barrier properties of triplex film coated with silicon oxide. Food Technology and Biotechnology, 41(3), 247-251. https:// hrcak.srce.hr/118634.

García-Moreno, P. J., Mendes, A. C., Jacobsen, C., \& Chronakis, I. S. (2018). Biopolymers for the nano-microencapsulation of bioactive ingredients by electrohydrodynamic processing. In T. J. Gutiérrez (Ed.), Polymers for food applications (pp. 447-479). Cham: Springer. https:// doi.org/10.1007/978-3-319-94625-2_17.

Garrido, T., Uranga, J., Guerrero, P., \& de la Caba, K. (2018). The potential of vegetal and animal proteins to develop more sustainable food packaging. In T. J. Gutiérrez (Ed.), Polymers for food applications (pp. 25-59). Cham: Springer. https://doi.org/10.1007/978-3-319-94625-2_3.

Gascon, J., Kapteijn, F., Zornoza, B., Sebastián, V., Casado, C., \& Coronas, J. (2012). Practical approach to zeolitic membranes and coatings: State of the art, opportunities, barriers, and future perspectives. Chemistry of Materials, 24(15), 2829-2844. https://doi.org/10.1021/cm301435j.

Ghasemlou, M., Khodaiyan, F., \& Oromiehie, A. (2011). Physical, mechanical, barrier, and thermal properties of polyol-plasticized biodegradable edible film made from kefiran. Carbohydrate Polymers, 84(1), 477-483. https://doi.org/10.1016/j.carbpol.2010.12.010.

Gorrasi, G., Bugatti, V., \& Sorrentino, A. (2018). Nanohybrid active fillers in food contact bio-based materials. In M. Jawaid \& S. K. Swain (Eds.), Bionanocomposites for packaging applications (pp. 71-94). Springer International Publishing. https://doi.org/10.1007/978-3-319-67319-6_4.

Guo, W., \& Chen, G. (2014). Fabrication of graphene/epoxy resin composites with much enhanced thermal conductivity via ball milling technique. Journal of Applied Polymer Science, 131(15). https://doi.org/10.1002/app.40565.

Gutiérrez, T. J. (2017a). Chapter 8. Chitosan applications for the food industry. In S. Ahmed \& S. Ikram (Eds.), Chitosan: Derivatives, composites and applications (pp. 183-232). 
EE.UU: WILEY-Scrivener Publisher. https://doi.org/10.1002/9781119364849.ch8. isbn:978-1-119-36350-7.

Gutiérrez, T. J. (2017b). Surface and nutraceutical properties of edible films made from starchy sources with and without added blackberry pulp. Carbohydrate Polymers, 165, 169-179. https://doi.org/10.1016/j.carbpol.2017.02.016.

Gutiérrez, T. J. (2018a). Active and intelligent films made from starchy sources/blackberry pulp. Journal Polymers and the Environment, 26(6), 2374-2391. https://doi.org/10.1007/ s10924-017-1134-y.

Gutiérrez, T. J. (2018b). Are modified pumpkin flour/plum flour nanocomposite films biodegradable and compostable? Food Hydrocolloids, 83, 397-410. https://doi.org/10.1016/j. foodhyd.2018.05.035.

Gutiérrez, T. J. (2018c). Biological macromolecule composite films made from sagu starch and flour/poly( $\varepsilon$-caprolactone) blends processed by blending/thermo molding. Journal Polymers and the Environment, 26(9), 3902-3912. https://doi.org/10.1007/s10924-018-1268-6.

Gutiérrez, T. J. (2018d). Characterization and in vitro digestibility of non-conventional starches from Guinea arrowroot and La Armuña lentils as potential food sources for special diet regimens. Starch-Stärke, 70(1-2). https://doi.org/10.1002/star.201700124.

Gutiérrez, T. J. (2018e). Chapter 55. Processing nano- and microcapsules for industrial applications. In C. M. Hussain (Ed.), Handbook of nanomaterials for industrial applications (pp. 989-1011). EE.UU: Editorial Elsevier. https://doi.org/10.1016/b978-0-12-813351-4.00057-2. isbn:978-0-12-813351-4.

Gutiérrez, T. J. (2018f). Chapter 9. Biodegradability and compostability of food nanopackaging materials. In G. Cirillo, M. A. Kozlowski, \& U. G. Spizzirri (Eds.), Composite materials for food packaging (pp. 269-296). EE.UU. ISBN: 978-1-119-16020-5: WILEY-Scrivener Publisher. https://doi.org/10.1002/9781119160243.ch9.

Gutiérrez, T. J. (2018g). Biological macromolecule composite films made from sagu starch and flour/poly( $\varepsilon$-caprolactone) blends processed by blending/thermo molding. Journal Polymers and the Environment, 26(9), 3902-3912. https://doi.org/10.1007/s10924-018-1268-6.

Gutiérrez, T. J., \& Álvarez, K. (2016). Physico-chemical properties and in vitro digestibility of edible films made from plantain flour with added Aloe vera gel. Journal of Functional Foods, 26, 750-762. https://doi.org/10.1016/j.jff.2016.08.054.

Gutiérrez, T. J., \& Álvarez, K. (2017a). Chapter 6. Biopolymers as microencapsulation materials in the food industry. In M. Masuelli \& D. Renard (Eds.), Advances in physicochemical properties of biopolymers: Part 2 (pp. 296-322). EE.UU. ISBN: 978-1-68108-545-6. eISBN: 978-1-68108-544-9, 2017: Bentham Science Publishers. https://doi.org/10.217 4/9781681085449117010009.

Gutiérrez, T. J., \& Alvarez, V. A. (2017a). Cellulosic materials as natural fillers in starch-containing matrix-based films: A review. Polymer Bulletin, 74(6), 2401-2430. https://doi.org/10.1007/ s00289-016-1814-0.

Gutiérrez, T. J., \& Álvarez, K. (2017b). Chapter 4: Transport phenomena in biodegradable and edible films. In M. A. Masuelli (Ed.), Biopackaging (pp. 58-88). Miami, EE.UU. ISBN: 978-1-4987-4968-8: Editorial CRC Press Taylor \& Francis Group. https://doi. org/10.1201/9781315152349-4.

Gutiérrez, T. J., \& Alvarez, V. A. (2017b). Properties of native and oxidized corn starch/polystyrene blends under conditions of reactive extrusion using zinc octanoate as a catalyst. Reactive and Functional Polymers, 112, 33-44. https://doi.org/10.1016/j.reactfunctpolym.2017.01.002.

Gutiérrez, T. J., \& Alvarez, V. A. (2017c). Eco-friendly films prepared from plantain flour/ PCL blends under reactive extrusion conditions using zirconium octanoate as a catalyst. Carbohydrate Polymers, 178, 260-269. https://doi.org/10.1016/j.carbpol.2017.09.026.

Gutiérrez, T. J., \& Alvarez, V. A. (2017d). Data on physicochemical properties of active films derived from plantain flour/PCL blends developed under reactive extrusion conditions. Data in Brief, 15, 445-448. https://doi.org/10.1016/j.dib.2017.09.071. 
Gutiérrez, T. J., \& Alvarez, V. A. (2017e). Films made by blending poly(e-caprolactone) with starch and flour from sagu rhizome grown at the Venezuelan Amazons. Journal Polymers and the Environment, 25(3), 701-716. https://doi.org/10.1007/s10924-016-0861-9.

Gutiérrez, T. J., \& Alvarez, V. A. (2018). Bionanocomposite films developed from corn starch and natural and modified nano-clays with or without added blueberry extract. Food Hydrocolloids, 77, 407-420. https://doi.org/10.1016/j.foodhyd.2017.10.017.

Gutiérrez, T. J., \& González, G. (2016). Effects of exposure to pulsed light on surface and structural properties of edible films made from cassava and taro starch. Food and Bioprocess Technology, 9(11), 1812-1824. https://doi.org/10.1007/s11947-016-1765-3.

Gutiérrez, T. J., \& González, G. (2017). Effect of cross-linking with Aloe vera gel on surface and physicochemical properties of edible films made from plantain flour. Food Biophysics, 12(1), 11-22. https://doi.org/10.1007/s11483-016-9458-z.

Gutiérrez, T. J., Pérez, E., Guzmán, R., Tapia, M. S., \& Famá, L. (2014). Physicochemical and functional properties of native and modified by crosslinking, dark-cush-cush yam (Dioscorea Trifida) and cassava (Manihot Esculenta) starch. Journal of Polymer and Biopolymer Physics Chemistry, 2(1), 1-5. https://doi.org/10.12691/jpbpc-2-1-1.

Gutiérrez, T. J., Morales, N. J., Pérez, E., Tapia, M. S., \& Famá, L. (2015a). Physico-chemical study of edible films based on native and phosphating cush-cush yam and cassava starches. Food Packaging and Shelf Life, 3, 1-8. https://doi.org/10.1016/j.fpsl.2014.09.002.

Gutiérrez, T. J., Tapia, M. S., Pérez, E., \& Famá, L. (2015b). Structural and mechanical properties of native and modified cush-cush yam and cassava starch edible films. Food Hydrocolloids, 45, 211-217. https://doi.org/10.1016/j.foodhyd.2014.11.017.

Gutiérrez, T. J., Tapia, M. S., Pérez, E., \& Famá, L. (2015c). Edible films based on native and phosphated 80:20 waxy:Normal corn starch. Starch-Stärke, 67(1-2), 90-97. https://doi. org/10.1002/star.201400164.

Gutiérrez, T. J., Morales, N. J., Tapia, M. S., Pérez, E., \& Famá, L. (2015d). Corn starch 80:20 "waxy": Regular, "native" and phosphated, as bio-matrixes for edible films. Procedia Materials Science, 8, 304-310. https://doi.org/10.1016/j.mspro.2015.04.077.

Gutiérrez, T. J., Guzmán, R., Medina Jaramillo, C., \& Famá, L. (2016a). Effect of beet flour on films made from biological macromolecules: Native and modified plantain flour. International Journal of Biological Macromolecules, 82, 395-403. https://doi.org/10.1016/j. ijbiomac.2015.10.020.

Gutiérrez, T. J., Suniaga, J., Monsalve, A., \& García, N. L. (2016b). Influence of beet flour on the relationship surface-properties of edible and intelligent films made from native and modified plantain flour. Food Hydrocolloids, 54, 234-244. https://doi.org/10.1016/j. foodhyd.2015.10.012.

Gutiérrez, T. J., González Seligra, P., Medina Jaramillo, C., Famá, L., \& Goyanes, S. (2017a). Chapter 14. Effect of filler properties on the antioxidant response of thermoplastic starch composites. In V. K. Thakur, M. K. Thakur, \& M. R. Kessler (Eds.), Handbook of composites from renewable materials (pp. 337-370). EE.UU. ISBN: 978-1-119-22362-7: WILEY-Scrivener Publisher. https://doi.org/10.1002/9781119441632.ch14.

Gutiérrez, T. J., Ponce, A. G., \& Alvarez, V. A. (2017b). Nano-clays from natural and modified montmorillonite with and without added blueberry extract for active and intelligent food nanopackaging materials. Materials Chemistry and Physics, 194, 283-292. https://doi. org/10.1016/j.matchemphys.2017.03.052.

Gutiérrez, T. J., Herniou-Julien, C., Álvarez, K., \& Alvarez, V. A. (2018a). Structural properties and in vitro digestibility of edible and $\mathrm{pH}$-sensitive films made from guinea arrowroot starch and wastes from wine manufacture. Carbohydrate Polymers, 184, 135-143. https://doi. org/10.1016/j.carbpol.2017.12.039.

Gutiérrez, T. J., Ollier, R., \& Alvarez, V. A. (2018b). Chapter 5. Surface properties of thermoplastic starch materials reinforced with natural fillers. In V. K. Thakur \& M. K. Thakur (Eds.), Functional biopolymers (pp. 131-158). EE.UU. ISBN: 978-3-319-66416-3. eISBN: 978-3-319-66417-0: Editorial Springer International Publishing. https://doi.org/10.1007/978-3-319-66417-0_5. 
Gutiérrez, T. J., Toro-Márquez, L. A., Merino, D., \& Mendieta, J. R. (2019). Hydrogen-bonding interactions and compostability of bionanocomposite films prepared from corn starch and nano-fillers with and without added Jamaica flower extract. Food Hydrocolloids, 89, 283-293. https://doi.org/10.1016/j.foodhyd.2018.10.058.

Helbert, W., Cavaillé, J. Y., \& Dufresne, A. (1996). Thermoplastic nanocomposites filled with wheat straw cellulose whiskers. Part I: Processing and mechanical behavior. Polymer Composites, 17(4), 604-611. https://doi.org/10.1002/pc.10650.

Hernandez-Izquierdo, V. M., \& Krochta, J. M. (2008). Thermoplastic processing of proteins for film formation - A review. Journal of Food Science, 73(2), 30-39. https://doi. org/10.1111/j.1750-3841.2007.00636.x.

Herniou--Julien, C., Mendieta, J. R., \& Gutiérrez, T. J. (2019). Characterization of biodegradable/non-compostable films made from cellulose acetate/corn starch blends processed under reactive extrusion conditions. Food Hydrocolloids, 89, 67-79. https://doi.org/10.1016/j. foodhyd.2018.10.024.

Heydari, A., Alemzadeh, I., \& Vossoughi, M. (2013). Functional properties of biodegradable corn starch nanocomposites for food packaging applications. Materials and Design, 50, 954-961. https://doi.org/10.1016/j.matdes.2013.03.084.

Hielscher, T. (2005). Ultrasonic Production of Nano-size Dispersions and Emulsions. European Nanosystems Conference (ENS'05). Paris-France.

Honarvar, Z., Hadian, Z., \& Mashayekh, M. (2016). Nanocomposites in food packaging applications and their risk assessment for health. Electronic Physician, 8(6), 2531-2538. https://doi. org/10.19082/2531.

Hsieh, S.-H., Zhang, F.-R., \& Li, H.-S. (2006). Anti-ultraviolet and physical properties of woolen fabrics cured with citric acid and $\mathrm{TiO}_{2} /$ chitosan. Journal of Applied Polymer Science, 100(6), 4311-4319. https://doi.org/10.1002/app.23830.

Hu, K., \& Tsukruk, V. V. (2015). Tuning the electronic properties of robust bio-bond graphene papers by spontaneous electrochemical reduction: From insulators to flexible semi-metals. Chemistry of Materials, 27(19), 6717-6729. https://doi.org/10.1021/acs.chemmater.5b02750.

Huang, J.-Y., Li, X., \& Zhou, W. (2015). Safety assessment of nanocomposite for food packaging application. Trends in Food Science \& Technology, 45(2), 187-199. https://doi.org/10.1016/j. tifs.2015.07.002.

Hussain, F., Hojjati, M., Okamoto, M., \& Gorga, R. E. (2006). Polymer-matrix nanocomposites, processing, manufacturing, and application: An overview. Journal of Composite Materials, 40(17), 1511-1575. https://doi.org/10.1177/0021998306067321.

Ilyas, R. A., Sapuan, S. M., Ishak, M. R., \& Zainudin, E. S. (2018). Development and characterization of sugar palm nanocrystalline cellulose reinforced sugar palm starch bionanocomposites. Carbohydrate Polymers, 202, 186-202. https://doi.org/10.1016/j.carbpol.2018.09.002.

Introzzi, L., Blomfeldt, T. O. J., Trabattoni, S., Tavazzi, S., Santo, N., Schiraldi, A., Piergiovanni, L., \& Farris, S. (2012). Ultrasound-assisted pullulan/montmorillonite bionanocomposite coating with high oxygen barrier properties. Langmuir, 28(30), 11206-11214. https://doi. org/10.1021/la301781n.

Jawaid, M., \& Swain, S. K. (2017). Bionanocomposites for packaging applications. In M. Jawaid \& S. K. Swain (Eds.), Bionanocomposites for packaging applications. https://doi. org/10.1007/978-3-319-67319-6.

Jiménez, A., Fabra, M. J., Talens, P., \& Chiralt, A. (2012). Edible and biodegradable starch films: A review. Food and Bioprocess Technology, 5(6), 2058-2076. https://doi.org/10.1007/ s11947-012-0835-4.

Kanmani, P., \& Rhim, J. W. (2014). Physical, mechanical and antimicrobial properties of gelatin based active nanocomposite films containing AgNPs and nanoclay. Food Hydrocolloids, 35, 644-652. https://doi.org/10.1016/j.foodhyd.2013.08.011.

Khan, R. A., Salmieri, S., Dussault, D., Uribe-Calderon, J., Kamal, M. R., Safrany, A., \& Lacroix, M. (2010). Production and properties of nanocellulose-reinforced methylcellulose-based bio- 
degradable films. Journal of Agricultural and Food Chemistry, 58(13), 7878-7885. https://doi. org/10.1021/jf1006853.

Khan, A., Huq, T., Khan, R. A., Riedl, B., \& Lacroix, M. (2014). Nanocellulose-based composites and bioactive agents for food packaging. Critical Reviews in Food Science and Nutrition, 54(2), 163-174. https://doi.org/10.1080/10408398.2011.578765.

Koo, J. H. (2006). Processing of nanomaterials. In Polymer Nanocomposites: Processing, characterization, and applications (pp. 61-78). McGraw-Hill.

Krishnamachari, P., Zhang, J., Lou, J., Yan, J., \& Uitenham, L. (2009). Biodegradable poly(lactic acid)/clay nanocomposites by melt intercalation: A study of morphological, thermal, and mechanical properties. International Journal of Polymer Analysis and Characterization, 14(4), 336-350. https://doi.org/10.1080/10236660902871843.

Kristo, E., \& Biliaderis, C. (2007). Physical properties of starch nanocrystal-reinforced pullulan films. Carbohydrate Polymers, 68(1), 146-158. https://doi.org/10.1016/j.carbpol.2006.07.021.

Kumar, M. N. V. R. (2000). A review of chitin and chitosan applications. Reactive \& Functional Polymers, 46(1), 1-27. https://doi.org/10.1016/S1381-5148(00)00038-9.

Kumar, P., Sandeep, K. P., Alavi, S., Truong, V. D., \& Gorga, R. E. (2010). Preparation and characterization of bio-nanocomposite films based on soy protein isolate and montmorillonite using melt extrusion. Journal of Food Engineering, 100(3), 480-489. https://doi.org/10.1016/j. jfoodeng.2010.04.035.

Kwak, H. W., Lee, H., Lee, M. E., \& Jin, H. J. (2018). Facile and green fabrication of silk sericin films reinforced with bamboo-derived cellulose nanofibrils. Journal of Cleaner Production, 200, 1034-1042. https://doi.org/10.1016/j.jclepro.2018.07.289.

Lacroix, M., \& Le Tien, C. (2005). Edible films and coatings from nonstarch polysaccharides. In J. H. Han (Ed.), Innovations in Food Packaging (pp. 338-361). Academic. https://doi. org/10.1016/b978-012311632-1/50052-8.

Lagarón, J. M. (2011). In J. M. Lagarón (Ed.), Multifunctional and nanoreinforced polymers for food packaging. Woodhead Publishing. https://doi.org/10.1533/9780857092786.1.

Lee, S. Y., Mohan, D. J., Kang, I. A., Doh, G. H., Lee, S., \& Han, S. O. (2009). Nanocellulose reinforced PVA composite films: Effects of acid treatment and filler loading. Fibers and Polymers, 10(1), 77-82. https://doi.org/10.1007/s12221-009-0077-x.

Li, S., Wei, Y., \& Huang, J. (2010). Facile fabrication of superhydrophobic cellulose materials by a nanocoating approach. Chemistry Letters, 39(1), 20-21. https://doi.org/10.1246/cl.2010.20.

Li, Y., Zhu, H., Zhu, S., Wan, J., Liu, Z., Vaaland, O., Lacey, S., Fang, Z., Dai, H., Li, T., \& Hu, L. (2015). Hybridizing wood cellulose and graphene oxide toward high-performance fibers. NPG Asia Materials, 7(1), e150-e150. https://doi.org/10.1038/am.2014.111.

Li, S., Donner, E., Thompson, M., Zhang, Y., Rempel, C., \& Liu, Q. (2017). Preparation and characterization of cross-linked canola protein isolate films. European Polymer Journal, 89, 419-430. https://doi.org/10.1016/j.eurpolymj.2017.03.001.

Llorens, A., Lloret, E., Picouet, P. A., Trbojevich, R., \& Fernandez, A. (2012). Metallic-based micro and nanocomposites in food contact materials and active food packaging. Trends in Food Science and Technology, 24(1), 19-29. https://doi.org/10.1016/j.tifs.2011.10.001.

Loher, S., Schneider, O. D., Maienfisch, T., Bokorny, S., \& Stark, W. J. (2008). Micro-organismtriggered release of silver nanoparticles from biodegradable oxide carriers allows preparation of self-sterilizing polymer surfaces. Small, 4(6), 824-832. https://doi.org/10.1002/ smll.200800047.

López, O. V., Castillo, L. A., García, M. A., Villar, M. A., \& Barbosa, S. E. (2015). Food packaging bags based on thermoplastic corn starch reinforced with talc nanoparticles. Food Hydrocolloids, 43, 18-24. https://doi.org/10.1016/j.foodhyd.2014.04.021.

López-León, T., Carvalho, E. L. S., Seijo, B., Ortega-Vinuesa, J. L., \& Bastos-González, D. (2005). Physicochemical characterization of chitosan nanoparticles: Electrokinetic and stability behavior. Journal of Colloid and Interface Science, 283(2), 344-351. https://doi.org/10.1016/j. jcis.2004.08.186. 
Lorenzo, G., Zaritzky, N., \& Califano, A. (2018). Food gel emulsions: Structural characteristics and viscoelastic behavior. In T. J. Gutiérrez (Ed.), Polymers for food applications (pp. 481-507). Cham: Springer. https://doi.org/10.1007/978-3-319-94625-2_18.

Ludueña, L. N., Alvarez, V. A., \& Vazquez, A. (2007). Processing and microstructure of PCL/ clay nanocomposites. Materials Science and Engineering A, 460-461, 121-129. https://doi. org/10.1016/j.msea.2007.01.104.

Luecha, J., Sozer, N., \& Kokini, J. L. (2010). Synthesis and properties of corn zein/montmorillonite nanocomposite films. Journal of Materials Science, 45(13), 3529-3537. https://doi. org/10.1007/s10853-010-4395-6.

Manias, E., Touny, A., Wu, L., Strawhecker, K., Lu, B., \& Chung, T. C. (2001). Polypropylene/ montmorillonite nanocomposites. Review of the synthetic routes and materials properties. Chemistry of Materials, 13(10), 3516-3523. https://doi.org/10.1021/cm0110627.

Marsh, K., \& Bugusu, B. (2007). Food packaging - Roles, materials, and environmental issues: Scientific status summary. Journal of Food Science, 72(3). https://doi. org/10.1111/j.1750-3841.2007.00301.x.

McEuen, P. L., Bockrath, M., Cobden, D. H., Yoon, Y.-G., \& Louie, S. G. (1999). Disorder, Pseudospins, and backscattering in carbon nanotubes. Physical Review Letters, 83(24), 5098-5101. https://doi.org/10.1103/physrevlett.83.5098.

Medeiros, E. S., Dufresne, A., \& Orts, W. J. (2010). Starch-based nanocomposites. In A. C. Bertolini (Ed.), Starches: Characterization, properties, and applications (pp. 205-251). CRC Press.

Medina Jaramillo, C., Gutiérrez, T. J., Goyanes, S., Bernal, C., \& Famá, L. (2016). Biodegradability and plasticizing effect of yerba mate extract on cassava starch edible films. Carbohydrate Polymers, 151, 150-159. https://doi.org/10.1016/j.carbpol.2016.05.025.

Merino, D., Gutiérrez, T. J., Mansilla, A. Y., Casalongué, C., \& Alvarez, V. A. (2018a). Critical evaluation of starch-based antibacterial nanocomposites as agricultural mulch films: Study on their interactions with water and light. ACS Sustainable Chemistry \& Engineering, 6(11), 15662-15672. https://doi.org/10.1021/acssuschemeng.8b04162.

Merino, D., Mansilla, A. Y., Gutiérrez, T. J., Casalongué, C. A., \& Alvarez, V. A. (2018b). Chitosan coated-phosphorylated starch films: Water interaction, transparency and antibacterial properties. Reactive and Functional Polymers, 131, 445-453. https://doi.org/10.1016/j. reactfunctpolym.2018.08.012.

Merino, D., Gutiérrez, T. J., \& Alvarez, V. A. (2019a). Structural and thermal properties of agricultural mulch films based on native and oxidized corn starch nanocomposites. Starch-Stärke, 71(7-8), 1800341. https://doi.org/10.1002/star.201800341.

Merino, D., Gutiérrez, T. J., \& Alvarez, V. A. (2019b). Potential agricultural mulch films based on native and phosphorylated corn starch with and without surface functionalization with chitosan. Journal Polymers and the Environment, 27(1), 97-105. https://doi.org/10.1007/ s10924-018-1325-1.

Miller, K. S., \& Krochta, J. M. (1997). Oxygen and aroma barrier properties of edible films: A review. Trends in Food Science and Technology, 8(7), 228-237. https://doi.org/10.1016/ s0924-2244(97)01051-0.

Morillon, V., Debeaufort, F., Blond, G., Capelle, M., \& Voilley, A. (2002). Factors affecting the moisture permeability of lipid-based edible films: A review. Critical Reviews in Food Science and Nutrition, 42(1), 67-89. https://doi.org/10.1080/10408690290825466.

Motedayen, A. A., Khodaiyan, F., \& Salehi, E. A. (2013). Development and characterisation of composite films made of kefiran and starch. Food Chemistry, 136(3-4), 1231-1238. https://doi. org/10.1016/j.foodchem.2012.08.073.

Murray, H. H. (2000). Traditional and new applications for kaolin, smectite, and palygorskite: A general overview. Applied Clay Science, 17(5-6), 207-221. https://doi.org/10.1016/ s0169-1317(00)00016-8.

Nair, S. S., Zhu, J., Deng, Y., \& Ragauskas, A. J. (2014). High performance green barriers based on nanocellulose. Sustainable Chemical Processes, 2(1), 1-7. https://doi.org/10.1186/ s40508-014-0023-0. 
Niu, X., Liu, Y., Song, Y., Han, J., \& Pan, H. (2018). Rosin modified cellulose nanofiber as a reinforcing and co-antimicrobial agents in polylactic acid /chitosan composite film for food packaging. Carbohydrate Polymers, 183, 102-109. https://doi.org/10.1016/j.carbpol.2017.11.079.

Ojijo, V., \& Sinha Ray, S. (2013). Processing strategies in bionanocomposites. Progress in Polymer Science, 38(10-11), 1543-1589. https://doi.org/10.1016/j.progpolymsci.2013.05.011.

Oksman, K., Mathew, A. P., Bondeson, D., \& Kvien, I. (2006). Manufacturing process of cellulose whiskers/polylactic acid nanocomposites. Composites Science and Technology, 66(15), 2776-2784. https://doi.org/10.1016/j.compscitech.2006.03.002.

Olivas, G. I., \& Barbosa-Cánovas, G. V. (2005). Edible coatings for fresh-cut fruits. Critical Reviews in Food Science and Nutrition, 45(7-8), 657-670. https://doi.org/10.1080/10408690490911837.

Oymaci, P., \& Altinkaya, S. A. (2016). Improvement of barrier and mechanical properties of whey protein isolate based food packaging films by incorporation of zein nanoparticles as a novel bionanocomposite. Food Hydrocolloids, 54(Part A), 1-9. https://doi.org/10.1016/j. foodhyd.2015.08.030.

Paralikar, S. A., Simonsen, J., \& Lombardi, J. (2008). Poly(vinyl alcohol)/cellulose nanocrystal barrier membranes. Journal of Membrane Science, 320(1-2), 248-258. https://doi.org/10.1016/j. memsci.2008.04.009.

Patel, A. R. (2018). Edible foams stabilized by food-grade polymers. In T. J. Gutiérrez (Ed.), Polymers for food applications (pp. 251-269). Cham: Springer. https:// doi.org/10.1007/978-3-319-94625-2_10.

Pavlidou, S., \& Papaspyrides, C. D. (2008). A review on polymer-layered silicate nanocomposites. Progress in Polymer Science, 33(12), 1119-1198. https://doi.org/10.1016/j. progpolymsci.2008.07.008.

Peacock, A. J., \& Calhoun, A. (2012). Polymer chemistry: Properties and application. Carl Hanser Verlag GmbH Co KG.

Pereda, M., Amica, G., Rácz, I., \& Marcovich, N. E. (2011). Structure and properties of nanocomposite films based on sodium caseinate and nanocellulose fibers. Journal of Food Engineering, 103(1), 76-83. https://doi.org/10.1016/j.jfoodeng.2010.10.001.

Pereda, M., Dufresne, A., Aranguren, M. I., \& Marcovich, N. E. (2014). Polyelectrolyte films based on chitosan/olive oil and reinforced with cellulose nanocrystals. Carbohydrate Polymers, 101(1), 1018-1026. https://doi.org/10.1016/j.carbpol.2013.10.046.

Pérez, S., Baldwin, P. M., \& Gallant, D. J. (2009). Structural features of starch granules I. In J. BeMiller \& R. Whistler (Eds.), Starch: Chemistry and technology (pp. 149-192). Academic. https://doi.org/10.1016/b978-0-12-746275-2.00005-7.

Petersson, L., \& Oksman, K. (2006). Biopolymer based nanocomposites: Comparing layered silicates and microcrystalline cellulose as nanoreinforcement. Composites Science and Technology, 66(13), 2187-2196. https://doi.org/10.1016/j.compscitech.2005.12.010.

Piermaria, J. A., Pinotti, A., Garcia, M. A., \& Abraham, A. G. (2009). Films based on kefiran, an exopolysaccharide obtained from kefir grain: Development and characterization. Food Hydrocolloids, 23(3), 684-690. https://doi.org/10.1016/j.foodhyd.2008.05.003.

Pillai, S. K., \& Sinha-Ray, S. (2015). Inorganic-organic hybrid polymers for food packaging. In G. Cirillo, U. G. Spizzirri, \& F. Iemma (Eds.), Functional polymers in food science: From technology to biology (pp. 281-322). John Wiley \& Sons. https://doi.org/10.1002/9781119109785.ch9.

Plackett, D. (2011). In D. Plackett (Ed.), Biopolymers - New materials for sustainable films and coatings. Wiley. https://doi.org/10.1002/9781119994312.

Puthussery, H., Prasad, R., Gorazda, K., \& Roy, I. (2015). Production, chemistry and properties of biopolymers in food science. In G. Cirillo, U. G. Spizzirri, \& F. Iemma (Eds.), Functional polymers in food science: From tchnology to biology (pp. 95-125). Wiley. https://doi. org/10.1002/9781119109785.ch4.

Qazanfarzadeh, Z., \& Kadivar, M. (2016). Properties of whey protein isolate nanocomposite films reinforced with nanocellulose isolated from oat husk. International Journal of Biological Macromolecules, 91, 1134-1140. https://doi.org/10.1016/j.ijbiomac.2016.06.077. 
Ramos, Ó. L., Fernandes, J. C., Silva, S. I., Pintado, M. E., \& Malcata, F. X. (2012). Edible films and coatings from whey proteins: A review on formulation, and on mechanical and bioactive properties. Critical Reviews in Food Science and Nutrition, 52(6), 533-552. https://doi.org/1 0.1080/10408398.2010.500528.

Rastogi, V., \& Samyn, P. (2015). Bio-based coatings for paper applications. Coatings, 5(4), 887-930. https://doi.org/10.3390/coatings5040887.

Reddy, J. P., \& Rhim, J. W. (2014). Characterization of bionanocomposite films prepared with agar and paper-mulberry pulp nanocellulose. Carbohydrate Polymers, 110, 480-488. https://doi. org/10.1016/j.carbpol.2014.04.056.

Rey, L., \& May, J. C. (2010). In L. Rey \& J. C. May (Eds.), Freeze-drying/lyophilization of pharmaceutical and biological products (3rd ed.). isbn:9781439825754.

Rhim, J. W. (2011). Effect of clay contents on mechanical and water vapor barrier properties of agar-based nanocomposite films. Carbohydrate Polymers, 86(2), 691-699. https://doi. org/10.1016/j.carbpol.2011.05.010.

Rhim, J. W., \& Shellhammer, T. H. (2005). Lipid-based edible films and coatings. In J. H. Han (Ed.), Innovations in food packaging (pp. 362-383). Academic. https://doi.org/10.1016/ b978-012311632-1/50053-x.

Rhim, J. W., \& Wang, L. F. (2014). Preparation and characterization of carrageenan-based nanocomposite films reinforced with clay mineral and silver nanoparticles. Applied Clay Science, 97-98, 174-181. https://doi.org/10.1016/j.clay.2014.05.025.

Rhim, J. W., Park, H. M., \& Ha, C. S. (2013). Bio-nanocomposites for food packaging applications. Progress in Polymer Science, 38(10-11), 1629-1652. https://doi.org/10.1016/j. progpolymsci.2013.05.008.

Richardson, J. J., Bjornmalm, M., \& Caruso, F. (2015). Technology-driven layer-by-layer assembly of nanofilms. Science, 348(6233), aaa2491. https://doi.org/10.1126/science.aaa2491.

Risch, S. J. (2009). Food packaging history and innovations. Journal of Agricultural and Food Chemistry, 57(18), 8089-8092. https://doi.org/10.1021/jf900040r.

Rives, V. (2001). In V. Rives (Ed.), Layered double hydroxides: Present and future. Nova Science Publishers Inc.

Robertson, G. L. (2013). Food packaging principles and practice (3rd ed.). https://doi. org/10.1201/b21347.

Robles, E., Salaberria, A. M., Herrera, R., Fernandes, S. C. M., \& Labidi, J. (2016). Self-bonded composite films based on cellulose nanofibers and chitin nanocrystals as antifungal materials. Carbohydrate Polymers, 144, 41-49. https://doi.org/10.1016/j.carbpol.2016.02.024.

Sakthivel, S., \& Pitchumani, B. (2011). Production of nano talc material and its applicability as filler in polymeric nanocomposites. Particulate Science and Technology, 29(5), 441-449. https://doi.org/10.1080/02726351.2010.510166.

Sanchez, C., Julián, B., Belleville, P., \& Popall, M. (2005). Applications of hybrid organic-inorganic nanocomposites. Journal of Materials Chemistry, 15(35-36), 3559-3592. https://doi. org/10.1039/b509097k.

Sanchez-Garcia, M. D., Gimenez, E., \& Lagaron, J. M. (2008a). Morphology and barrier properties of nanobiocomposites of poly (3-hydroxybutyrate) and layered silicates. Journal of Applied Polymer Science, 108(5), 2787-2801. https://doi.org/10.1002/app.

Sanchez-Garcia, M. D., Gimenez, E., \& Lagaron, J. M. (2008b). Morphology and barrier properties of solvent cast composites of thermoplastic biopolymers and purified cellulose fibers. Carbohydrate Polymers, 71(2), 235-244. https://doi.org/10.1016/j.carbpol.2007.05.041.

Savadekar, N. R., Karande, V. S., Vigneshwaran, N., Bharimalla, A. K., \& Mhaske, S. T. (2012). Preparation of nano cellulose fibers and its application in kappa-carrageenan based film. International Journal of Biological Macromolecules, 51(5), 1008-1013. https://doi. org/10.1016/j.ijbiomac.2012.08.014.

Shankar, S., \& Rhim, J. W. (2016a). Polymer Nanocomposites for food packaging applications. In A. Dasari \& J. Njuguna (Eds.), Functional and Physical Properties of Polymer Nanocomposites (pp. 29-55). John Wiley \& Sons. https://doi.org/10.1002/9781118542316.ch3. 
Shankar, S., \& Rhim, J. W. (2016b). Preparation of nanocellulose from micro-crystalline cellulose: The effect on the performance and properties of agar-based composite films. Carbohydrate Polymers, 135, 18-26. https://doi.org/10.1016/j.carbpol.2015.08.082.

Siracusa, V. (2012). Food packaging permeability behaviour: A report. International Journal of Polymer Science, 302029. https://doi.org/10.1155/2012/302029.

Siracusa, V., Rocculi, P., Romani, S., \& Rosa, M. D. (2008). Biodegradable polymers for food packaging: A review. Trends in Food Science and Technology, 19(12), 634-643. https://doi. org/10.1016/j.tifs.2008.07.003.

Soheilmoghaddam, M., Wahit, M. U., Tuck Whye, W., Ibrahim Akos, N., Heidar Pour, R., \& Ali Yussuf, A. (2014). Bionanocomposites of regenerated cellulose/zeolite prepared using environmentally benign ionic liquid solvent. Carbohydrate Polymers, 106, 326-334. https://doi. org/10.1016/j.carbpol.2014.02.085.

Sondi, I., \& Salopek-Sondi, B. (2004). Silver nanoparticles as antimicrobial agent: A case study on E. coli as a model for gram-negative bacteria. Journal of Colloid and Interface Science, 275(1), 177-182. https://doi.org/10.1016/j.jcis.2004.02.012.

Song, Z., Xiao, H., \& Zhao, Y. (2014). Hydrophobic-modified nano-cellulose fiber/PLA biodegradable composites for lowering water vapor transmission rate (WVTR) of paper. Carbohydrate Polymers, 111, 442-448. https://doi.org/10.1016/j.carbpol.2014.04.049.

Sorrentino, A., Gorrasi, G., Tortora, M., Vittoria, V., Costantino, U., Marmottini, F., \& Padella, F. (2005). Incorporation of $\mathrm{Mg}$-Al hydrotalcite into a biodegradable poly( $\varepsilon$-caprolactone) by high energy ball milling. Polymer, 46(5), 1601-1608. https://doi.org/10.1016/j. polymer.2004.12.018.

Sothornvit, R., Rhim, J. W., \& Hong, S. I. (2009). Effect of nano-clay type on the physical and antimicrobial properties of whey protein isolate/clay composite films. Journal of Food Engineering, 91(3), 468-473. https://doi.org/10.1016/j.jfoodeng.2008.09.026.

Souza, A. C., Benze, R., Ferrão, E. S., Ditchfield, C., Coelho, A. C. V., \& Tadini, C. C. (2012). Cassava starch biodegradable films: Influence of glycerol and clay nanoparticles content on tensile and barrier properties and glass transition temperature. LWT - Food Science and Technology, 46(1), 110-117. https://doi.org/10.1016/j.lwt.2011.10.018.

Suárez, G., \& Gutiérrez, T. J. (2017). Chapter 15. Recent advances in the development of biodegadable films and foams from cassava starch. In C. Klein (Ed.), Handbook on cassava: Production, potential uses and recent advances (pp. 297-312). New York. EE.UU: Editorial Nova Science Publishers, Inc. isbn:978-1-53610-307-6.

Sun, J., Zhou, W., Huang, D., \& Yan, L. (2018). 3D food printing: Perspectives. In T. J. Gutiérrez (Ed.), Polymers for food applications (pp. 725-755). Cham: Springer. https:// doi.org/10.1007/978-3-319-94625-2_26.

Svagan, A. J., Hedenqvist, M. S., \& Berglund, L. (2009). Reduced water vapour sorption in cellulose nanocomposites with starch matrix. Composites Science and Technology, 69(3-4), 500-506. https://doi.org/10.1016/j.compscitech.2008.11.016.

Swain, S. K., Sarkar, N., Patra, B., \& Sahoo, G. (2018). Polymer-based bionanocomposites for future packaging materials. In M. Jawaid \& S. K. Swain (Eds.), Bionanocomposites for packaging applications (pp. 33-48). Springer International Publishing. https://doi. org/10.1007/978-3-319-67319-6_2.

Tang, X. Z., Kumar, P., Alavi, S., \& Sandeep, K. P. (2012). Recent advances in biopolymers and biopolymer-based nanocomposites for food packaging materials. Critical Reviews in Food Science and Nutrition, 52(5), 426-442. https://doi.org/10.1080/10408398.2010.500508.

Tapia-Blácido, D. R., Maniglia, B. C., \& Tosi, M. M. (2018). Transport phenomena in edible films. In T. J. Gutiérrez (Ed.), Polymers for food applications (pp. 149-192). Cham: Springer. https:// doi.org/10.1007/978-3-319-94625-2_7.

Tharanathan, R. N. (2003). Biodegradable films and composite coatings: Past, present and future. Trends in Food Science and Technology, 14(3), 71-78. https://doi.org/10.1016/ s0924-2244(02)00280-7. 
Thiré, R. M. d. S. M. (2010). Starch-based plastics. In A. C. Bertolini (Ed.), Starches: Characterization, properties, and applications (pp. 103-128). CRC Press.

Tomadoni, B., Capello, C., Valencia, G. A., \& Gutiérrez, T. J. (2020). Self-assembled proteins for food applications: A review. Trends in Food Science \& Technology, 101, 1-16. https://doi. org/10.1016/j.tifs.2020.04.015.

Toro-Márquez, L. A., Merino, D., \& Gutiérrez, T. J. (2018). Bionanocomposite films prepared from corn starch with and without nanopackaged Jamaica (Hibiscus sabdariffa) flower extract. Food and Bioprocess Technology, 11(11), 1955-1973. https://doi.org/10.1007/s11947-018-2160-z.

Tunc, S., Angellier, H., Cahyana, Y., Chalier, P., Gontard, N., \& Gastaldi, E. (2007). Functional properties of wheat gluten/montmorillonite nanocomposite films processed by casting. Journal of Membrane Science, 289(1-2), 159-168. https://doi.org/10.1016/j.memsci.2006.11.050.

Turan, D., Gunes, G., \& Kilic, A. (2018). Perspectives of bio-nanocomposites for food packaging applications. In M. Jawaid \& S. K. Swain (Eds.), Bionanocomposites for packaging applications (pp. 1-32). https://doi.org/10.1007/978-3-319-67319-6_1.

Unalan, I. U., Cerri, G., Marcuzzo, E., Cozzolino, C. A., \& Farris, S. (2014). Nanocomposite films and coatings using inorganic nanobuilding blocks (NBB): Current applications and future opportunities in the food packaging sector. RSC Advances, 4(56), 29393-29428. https://doi. org/10.1039/c4ra01778a.

Vaia, R. A., \& Giannelis, E. P. (1997). Lattice model of polymer melt intercalation in organicallymodified layered silicates. Macromolecules, 30(25), 7990-7999. https://doi.org/10.1021/ ma9514333.

Vaia, R. A., Jandt, K. D., Kramer, E. J., \& Giannelis, E. P. (1996). Microstructural evolution of melt intercalated polymer-organically modified layered silicates nanocomposites. Chemistry of Materials, 8(11), 2628-2635. https://doi.org/10.1021/cm960102h.

Valencia, G. A., Luciano, C. G., Lourenço, R. V., \& do Amaral Sobral, P. J. (2018). Microstructure and physical properties of nano-biocomposite films based on cassava starch and laponite. International Journal of Biological Macromolecules, 107(Part B), 1576-1583. https://doi. org/10.1016/j.ijbiomac.2017.10.031.

Valencia, G. A., Zare, E. N., Makvandi, P., \& Gutiérrez, T. J. (2019). Self-assembled carbohydrate polymers for food applications: A review. Comprehensive Reviews in Food Science and Food Safety.https://doi.org/10.1111/1541-4337.12499.

Vartiainen, J., Tuominen, M., \& Nättinen, K. (2010). Bio-hybrid nanocomposite coatings from sonicated chitosan and nanoclay. Journal of Applied Polymer Science, 116(6), 3638-3647. https://doi.org/10.1002/app.31922.

Vartiainen, J., Vähä-Nissi, M., \& Harlin, A. (2014). Biopolymer films and coatings in packaging applications-A review of recent developments. Materials Sciences and Applications, 5(10), 708-718. https://doi.org/10.4236/msa.2014.510072.

Vigneshwaran, N., Ammayappan, L., \& Huang, Q. (2011). Effect of gum arabic on distribution behavior of nanocellulose fillers in starch film. Applied Nanoscience, 1(3), 137-142. https:// doi.org/10.1007/s13204-011-0020-5.

Vilarinho, F., Sanches Silva, A., Vaz, M. F., \& Farinha, J. P. (2018). Nanocellulose in green food packaging. Critical Reviews in Food Science and Nutrition, 58(9), 1526-1537. https://doi.org/1 0.1080/10408398.2016.1270254.

Villa, C. C., Sanchez, L. T., \& Rodriguez-Marin, N. D. (2019). Starch nanoparticles and nanocrystals as bioactive molecule carriers. In T. J. Gutiérrez (Ed.), Polymers for Aagri-food applications (pp. 91-98). Cham: Springer. https://doi.org/10.1007/978-3-030-19416-1_6.

Wang, J., Cheng, Q., Lin, L., \& Jiang, L. (2014). Synergistic toughening of bioinspired poly(vinyl alcohol)-clay-nanofibrillar cellulose artificial nacre. ACS Nano, 8(3), 2739-2745. https://doi. org/10.1021/nn406428n.

Wang, Y., Aurelio, D., Li, W., Tseng, P., Zheng, Z., Li, M., Kaplan, D. L., Liscidini, M., \& Omenetto, F. G. (2017). Modulation of multiscale 3D lattices through conformational control: Painting silk inverse opals with water and light. Advanced Materials, 29(38), 1702769. https:// doi.org/10.1002/adma.201702769. 
Weiss, J., Takhistov, P., \& McClements, D. J. (2006). Functional materials in food nanotechnology. Journal of Food Science, 71(9), R107-R116. https://doi. org/10.1111/j.1750-3841.2006.00195.x.

Xie, F., Pollet, E., Halley, P. J., \& Avérous, L. (2013). Starch-based nano-biocomposites. Progress in Polymer Science, 38(10-11), 1590-1628. https://doi.org/10.1016/j.progpolymsci.2013.05.002.

Xiong, R., Grant, A. M., Ma, R., Zhang, S., \& Tsukruk, V. V. (2018). Naturally-derived biopolymer nanocomposites: Interfacial design, properties and emerging applications. Materials Science and Engineering: R: Reports, 125, 1-41. https://doi.org/10.1016/j.mser.2018.01.002.

Xu, Y. X., Kim, K. M., Hanna, M. A., \& Nag, D. (2005). Chitosan-starch composite film: Preparation and characterization. Industrial Crops and Products, 21(2), 185-192. https://doi. org/10.1016/j.indcrop.2004.03.002.

Xu, B., Zheng, Q., Song, Y., \& Shangguan, Y. (2006). Calculating barrier properties of polymer/clay nanocomposites: Effects of clay layers. Polymer, 47(8), 2904-2910. https://doi.org/10.1016/j. polymer.2006.02.069.

Yah, W. O., Xu, H., Soejima, H., Ma, W., Lvov, Y., \& Takahara, A. (2012). Biomimetic dopamine derivative for selective polymer modification of halloysite nanotube lumen. Journal of the American Chemical Society, 134(29), 12134-12137. https://doi.org/10.1021/ja303340f.

Yan, J., Zhou, G., Knight, D. P., Shao, Z., \& Chen, X. (2010). Wet-spinning of regenerated silk fiber from aqueous silk fibroin solution: Discussion of spinning parameters. Biomacromolecules, 11(1), 1-5. https://doi.org/10.1021/bm900840h.

Yildirim, S., Röcker, B., Pettersen, M. K., Nilsen-Nygaard, J., Ayhan, Z., Rutkaite, R., Radusin, T., Suminska, P., Marcos, B., \& Coma, V. (2018). Active packaging applications for food. Comprehensive Reviews in Food Science and Food Safety, 17(1), 165-199. https://doi. org/10.1111/1541-4337.12322.

Yoon, P. J., Fornes, T. D., \& Paul, D. R. (2002). Thermal expansion behavior of nylon 6 nanocomposites. Polymer, 43(25), 6727-6741. https://doi.org/10.1016/s0032-3861(02)00638-9.

Youssef, A. M. (2013). Polymer nanocomposites as a new trend for packaging applications. Polymer-Plastics Technology and Engineering, 52(7), 635-660. https://doi.org/10.108 0/03602559.2012.762673.

Yu, Y. H., Lin, C. Y., Yeh, J. M., \& Lin, W. H. (2003). Preparation and properties of poly(vinyl alcohol)-clay nanocomposite materials. Polymer, 44(12), 3553-3560. https://doi.org/10.1016/ s0032-3861(03)00062-4.

Zeman, S. (2007). Mechanical properties to measure resistance of food packaging materials to external influences. Technical Sciences, 10, 35-40. https://doi.org/10.2478/v10022-007-0005-5.

Zhao, C., Qin, H., Gong, F., Feng, M., Zhang, S., \& Yang, M. (2005). Mechanical, thermal and flammability properties of polyethylene/clay nanocomposites. Polymer Degradation and Stability, 87(1), 183-189. https://doi.org/10.1016/j.polymdegradstab.2004.08.005.

Zhou, X., Shin, E., Wang, K. W., \& Bakis, C. E. (2004). Interfacial damping characteristics of carbon nanotube-based composites. Composites Science and Technology, 64(15), 2425-2437. https://doi.org/10.1016/j.compscitech.2004.06.001.

Zia, F., Zia, K. M., Zuber, M., Kamal, S., \& Aslam, N. (2015). Starch based polyurethanes: A critical review updating recent literature. Carbohydrate Polymers, 134, 784-798. https://doi. org/10.1016/j.carbpol.2015.08.034.

Zolfi, M., Khodaiyan, F., Mousavi, M., \& Hashemi, M. (2014). The improvement of characteristics of biodegradable films made from kefiran-whey protein by nanoparticle incorporation. Carbohydrate Polymers, 109, 118-125. https://doi.org/10.1016/j.carbpol.2014.03.018. 